\title{
COMBINAÇÕES DE DOSES DE FÓSFORO E DE ZINCO EM SOLUÇÃO NUTRITIVA PARA O CAPIM-TANZÂNIA
}

\author{
SIMEIRE APARECIDA MANARIN
}

Dissertação apresentada à Escola Superior de Agricultura "Luiz de Queiroz", Universidade de São Paulo, para obtenção do título de Mestre em Agronomia, Área de Concentração: Solos e Nutrição de Plantas.

P I R A C I C A B A

Estado de São Paulo - Brasil Julho - 2005 


\title{
COMBINAÇÕES DE DOSES DE FÓSFORO E DE ZINCO EM SOLUÇÃO NUTRITIVA PARA O CAPIM-TANZÂNIA
}

\section{SIMEIRE APARECIDA MANARIN}

Engenheiro Agrônomo

Orientador: Prof. Dr. FRANCISCO ANTONIO MONTEIRO

\begin{abstract}
Dissertação apresentada à Escola Superior de Agricultura "Luiz de Queiroz", Universidade de São Paulo, para obtenção do título de Mestre em Agronomia, Área de Concentração: Solos e Nutrição de Plantas.
\end{abstract}

P I R A C I C A B A

Estado de São Paulo - Brasil Julho - 2005 
Dados Internacionais de Catalogação na Publicação (CIP) DIVISÃO DE BIBLIOTECA E DOCUMENTAÇÃO - ESALQ/USP

Manarin, Simeire Aparecida

Combinações de doses de fósforo e de zinco em solução nutritiva para o

Capim-Tanzânia / Simeire Aparecida Manarin. - - Piracicaba, 2005.

68 p. : il.

Dissertação (mestrado) - - Escola Superior de Agricultura Luiz de Queiroz, 2005.

Bibliografia.

1. Adubação fosfatada 2. Capim-Tanzânia 3. Solução nutritiva 4. Zinco I. Título

CDD 633.2

"Permitida a cópia total ou parcial deste documento, desde que citada a fonte - $\mathrm{O}$ autor" 
Aos meus amados pais Orlando e Clarisse (in memorian)

AGRADEÇO

Ao meu namorado Vinicius

Aos meus irmãos Sueli, Sandra, Sidinei e Cirlene

DEDICO

Aos meus cunhados, sobrinhos, padrinhos e familiares 


\section{AGRADECIMENTOS}

À Deus, por ter me concedido saúde, paz e por estar sempre ao meu lado.

Ao professor Francisco Antonio Monteiro, pela orientação, compreensão e amizade.

Aos professores Antonio Roque Dechen e Quirino Augusto de Camargo Carmello pelos ensinamentos.

A todos os professores do Departamento de Solos e Nutrição de Plantas da ESALQ/USP, pelo apoio científico.

Ao professor Carlos Alberto Labate, pela ajuda no desenvolvimento do trabalho realizado no Laboratório de Genética Fisiológica.

Às funcionárias do Laboratório de Nutrição de Plantas da ESALQ/USP Edinéia C. S. Mondoni, Lúcia Helena S. P. Forti, Lurdes de A. D. Gonzáles, Nivanda M. M. Ruiz e Sueli M. A.A. C. Bovi, pela imensa cooperação nas análises químicas.

Aos estagiários de Nutrição Mineral de Plantas da ESALQ/USP, em especial a Larissa Marcondes, pela contribuição no desenvolvimento do trabalho.

Aos colegas de pós-graduação, Alessandra Giacomini, Cristiane Silveira, Dylnei Consolmagno Neto, Edna Bonfim, Fabiano D. de Bona, Gilberto Nava, Gilmar Nachtigall, Haroldo Hoogerheide, Jackson L. Lange, João de Deus Santos Júnior, José Olímpio de Souza Júnior, Karina Batista, Suzana Melo e Valdomiro de Souza Júnior pela ajuda e amizade. 
À CAPES pela bolsa concedida e pelo apoio financeiro e institucional prestado para a realização deste trabalho.

Aos meus queridos pais Orlando Manarin e Clarisse Bernardi Manarin, pelo carinho, educação e ensinamentos.

Aos meus estimados irmãos, Sueli, Sidinei e Sandra pela incondicional amizade e zelo e, em especial, à minha irmã Cirlene Aparecida Manarin, que me precedeu neste meio acadêmico, servindo de paradigma.

Ao meu namorado, Vinicius Marcelo Rocha pelo amor, amizade, cumplicidade e incentivo.

As minhas amigas Camila M. Patreze, Maria Augusta P. Tonim, Maria Cecília P. Paggiaro, Fátima Oshiro e ao meu primo Walter Fernando Bernardi pela amizade e compreensão. 


\section{SUMÁRIO}

Página

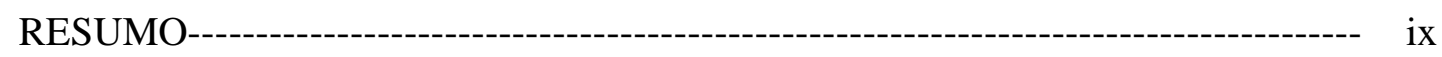

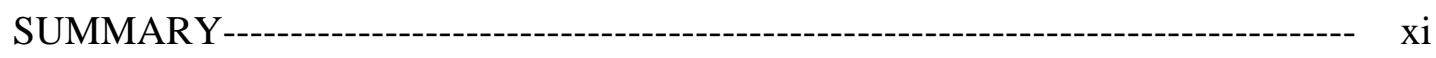

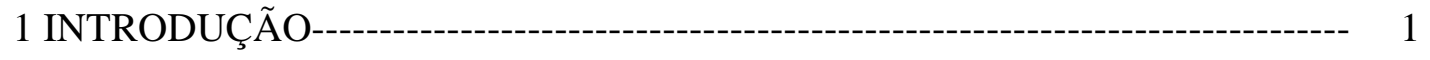

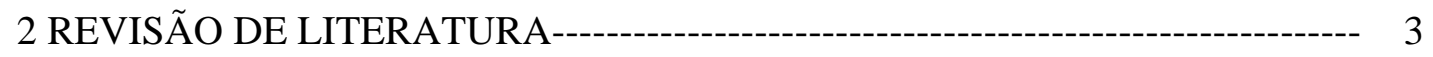

2.1 Capim-Tanzânia----------------------------------------------------------------------------- 3

2.2 Fósforo----------------------------------------------------------------------------------------- 4

2.2.1 Respostas das gramíneas forrageiras à adubação fosfatada----------------------- 4

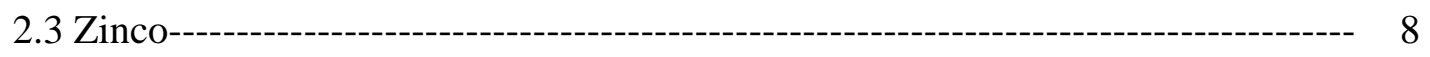

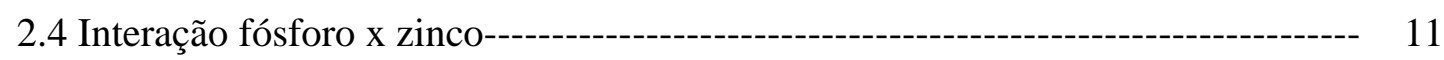

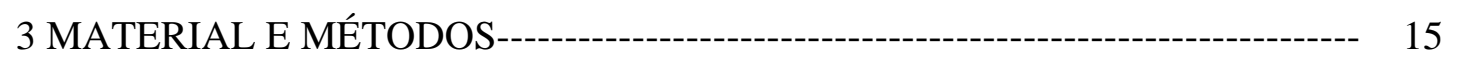

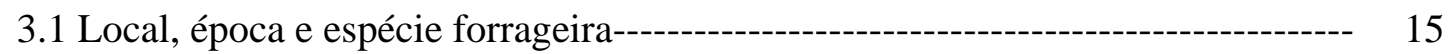

3.2 Doses de fósforo e de zinco e delineamento experimental-------------------------- 15

3.3 Condução do experimento------------------------------------------------------------ 17

3.4 Emissão de perfilhos e de folhas------------------------------------------------------- 18

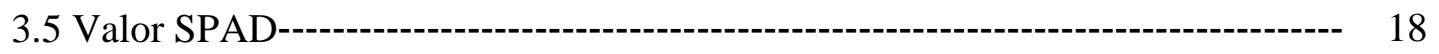




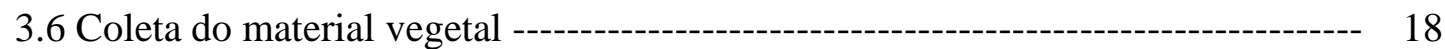

3.7 Determinação da área foliar----19 19

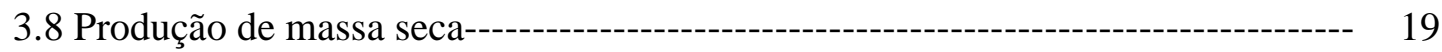

3.9 Composição mineral do tecido vegetal----------------------------------------------- 19

3.10 Determinação da clorofila------------------------------------------------------------ 20

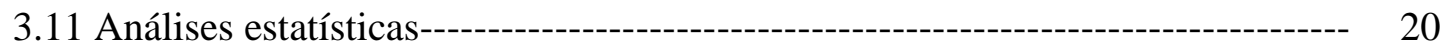

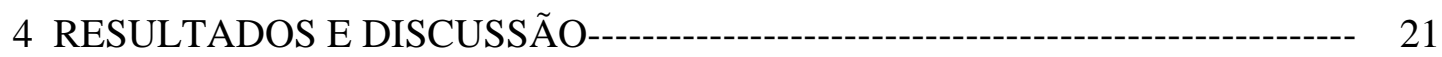

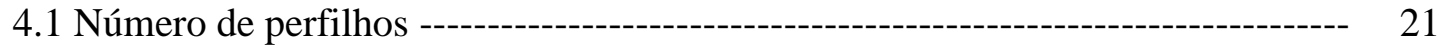

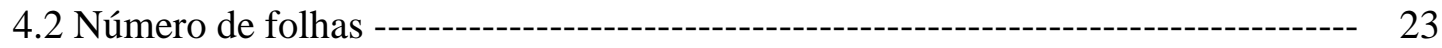

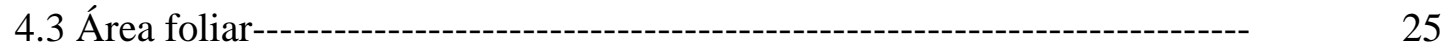

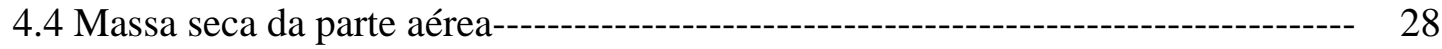

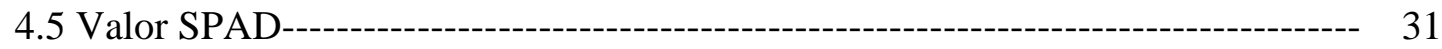

4.6 Clorofila na parte aérea---- 32

4.7 Massa seca, comprimento, comprimento específico e superfície radicular------- 33

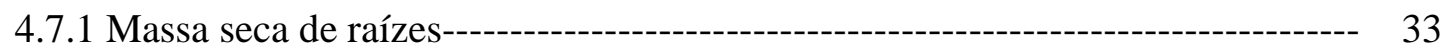

4.7.2 Comprimento das raízes--- 34

4.7.3.Comprimento específico de raízes---------------------------------------------------- 35

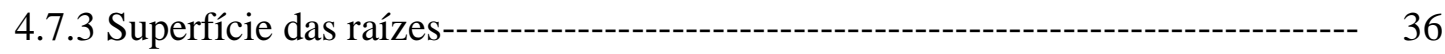

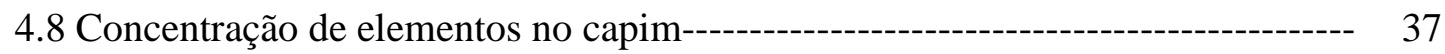

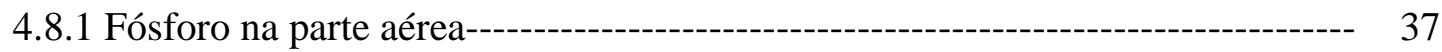

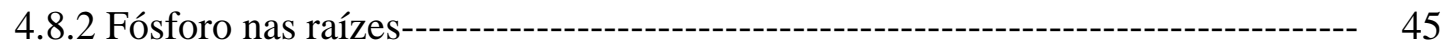

4.8.3 Zinco na parte aérea----------------------------------------------------------- 46 


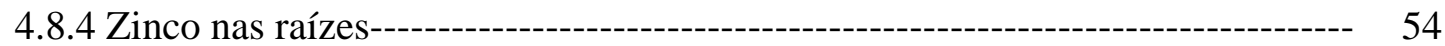

4.9 Sintomas visuais --- 55

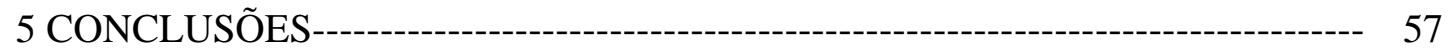

REFERÊNCIAS BIBLIOGRÁFICAS------------------------------------------------------ 59 


\title{
COMBINAÇÕES DE DOSES DE FÓSFORO E DE ZINCO EM SOLUÇÃO NUTRITIVA PARA O CAPIM-TANZÂNIA
}

\author{
Autora: SIMEIRE APARECIDA MANARIN \\ Orientador: Prof. Dr. FRANCISCO ANTONIO MONTEIRO
}

\section{RESUMO}

As pastagens são a principal fonte de alimento para o rebanho bovino no Brasil e elas são constituídas principalmente por gramíneas. Entre as espécies dominantes a Panicum maximum destaca-se pela sua boa produtividade e alto valor nutritivo. Para a formação e a manutenção dos pastos, o fornecimento e o balanço entre nutrientes na planta assumem importância fundamental. Neste estudo objetivou-se avaliar as respostas do Panicum maximum cv. Tanzânia, a combinações de doses de fósforo e de zinco na solução nutritiva, quanto aos parâmetros morfofisiológicos e produtivos e às concentrações de fósforo e zinco nos tecidos. Realizou-se um experimento na casa-de-vegetação localizada em Piracicaba, Estado de São Paulo, com o capim-Tanzânia no período de verão. Foram testadas cinco doses de fósforo $\left(0,2,0,6,1,0,1,4\right.$ e $\left.1,8 \mathrm{mmol} \mathrm{L}^{-1}\right)$ e cinco de zinco $(0,00,0,25,0,50,0,75,1,00$ $\mu \mathrm{mol} \mathrm{L}^{-1}$ ) num estudo em superfície de resposta, baseado no desenho experimental composto central modificado de um esquema fatorial $5^{2}$ incompleto resultando em 13 combinações de doses. Para os demais nutrientes as soluções foram baseadas na completa de Sarruge (1975) modificada apenas para nitrogênio fornecido na dose de $30 \mathrm{mmol} \mathrm{L}^{-1}$. As trocas de soluções 
foram efetuadas a cada 14 dias. Colocaram-se cinco plantas em vasos de 3,6 L, utilizando-se sílica como substrato. Aos 32 dias após o transplante procedeu-se o primeiro corte das plantas e aos 28 dias após o primeiro realizou-se 0 segundo corte. Imediatamente após cada corte o material vegetal foi separado em: folhas emergentes (FE), lâminas de folhas recém-expandidas (LR), lâminas de folhas maduras (LM) e colmos + bainhas (CB). Após o segundo corte, realizou-se a coleta das raízes. As partes das plantas coletadas nos dois cortes foram colocadas para secar, determinou-se a massa seca das plantas e a moagem para posterior análise no laboratório. Os resultados mostraram significâncias para a interação entre as doses de fósforo e as de zinco na massa seca da parte aérea do primeiro corte, na área foliar do segundo corte, na massa seca de raízes, nas concentrações de fósforo nas LM coletadas no primeiro e segundo cortes, na concentração média de fósforo na parte aérea das plantas e na concentração de zinco nas FE no primeiro crescimento. A massa seca da parte aérea no segundo crescimento, a área foliar no primeiro crescimento, os números de folhas e perfilhos no primeiro e segundo crescimentos, valor SPAD no primeiro crescimento, comprimento, comprimento específico e superfície de raízes, concentração de fósforo nas FE, LR e CB no primeiro e segundo crescimentos, concentração média de fósforo na parte aérea no segundo crescimento, concentração de fósforo nas raízes, concentração de zinco nas LR, LM e CB coletada tanto no primeiro como no segundo cortes e concentração de zinco nas FE amostradas no segundo corte variou significativamente com as doses de fósforo na solução. As doses de zinco influenciaram significativamente a área foliar e a concentração de zinco nas LM do primeiro corte. 


\title{
COMBINATIONS OF PHOSPHORUS AND ZINC RATES IN NUTRIENT SOLUTION FOR TANZÂNIA GRASS
}

\author{
Author: SIMEIRE APARECIDA MANARIN \\ Adviser : Prof. Dr. FRANCISCO ANTONIO MONTEIRO
}

\section{SUMMARY}

Pastures are the main food source for de cattle in Brazil, and the grasses occupy most of them. Among the species in those pastures, Panicum maximum is preferred for its productivity and quality. In order to establish and maintain the pastures, it is necessary to supply nutrients in balanced amounts. The objective of this study was to determine the Panicum maximum cv. Tanzânia responses to combinations of phosphorus and zinc rates in nutrient solution related to the morphophysiology, yield and the concentrations of phosphorus and zinc in plant tissues. An experiment was carried out in a greenhouse located at Piracicaba, State of Sao Paulo, Brazil, with Tanzânia grass, in Summer season. Five rates of phosphorus $(0.2,0.6,1.0,1.4$ e 1.8 $\left.\mathrm{mmol} \mathrm{L}^{-1}\right)$ and five rates of zinc $\left(0.00,0.25,0.50,0.75,1.00 \mu \mathrm{mol} \mathrm{L}^{-1}\right)$ were studied in a response surface methodology, based on a modified central composite design of a fractional $5^{2}$ factorial. Other nutrients had concentrations in solution as recommended by Sarruge (1975), except for nitrogen that was supplied at $30 \mathrm{mmol} \mathrm{L}^{-1}$. Five plants were grown in $3.6 \mathrm{~L}$ plastic pots, containing ground quartz. The first harvest was done at 32 days after seedlings 
transplanting to the pots, and the second harvest was accomplished at 28 days after the first one. At the time of each harvest plant tops were separated into: emergents leaves (EL), lamina of recently expanded leaves $(R L)$, lamina of mature leaves (ML) and colms + sheaths (CS). After the second harvest the roots werw collected. All plant material was dried, weighed and ground for laboratory analysis. The results showed that the interaction between phosphorus and zinc rates was significant for the dry matter yield at the first harvest, leaf area at the second harvest, roots dry weight, phosphorus concentration in the $\mathrm{ML}$ at the first and second harvests, in both the average phosphorus concentration in plant tops and zinc concentration in EL at the first harvest. Dry matter yield at the second harvest, leaf area at the first harvest, numbers of tillers and leaves at the first and second harvest, SPAD value in the first harvest, roots length, specific length and surface, phosphorus concentrations in the EL, RL and CS at the first and second harvests, the average phosphorus concentration in plant tops at the second harvest, phosphorus concentration in the roots, zinc concentrations in the RL, ML, and CS at the first and second harvests, and zinc concentration in the EL at the second harvest significantly changed with phosphorus rates. Significant responses to zinc rates were obtained for leaf area and zinc concentration in $\mathrm{ML}$ in first growth. 


\section{INTRODUÇÃO}

As pastagens são a principal fonte de alimentação para os ruminantes, predominando nelas as gramíneas forrageiras. Da área total mundial de aproximadamente 13,4 bilhões de hectares, cerca de 3,5 bilhões são ocupados por pastagens.

Uma espécie de plantas forrageiras que tem mantido por muito tempo o interesse de produtores e pesquisadores brasileiros é o Panicum maximum, devido sua boa produtividade e alto valor nutritivo. Dentre os diversos cultivares desta espécie, o capim-Tanzânia tem sido uma opção no Brasil para sistemas com manejo mais intensivo.

A adubação figura como tecnologia indispensável para a formação e manutenção das pastagens. Solos que são férteis e profundos permitem o cultivo de forrageiras mais nobres, enquanto os de baixa fertilidade suportam plantas de menor rendimento forrageiro e baixo valor nutritivo, apresentando níveis baixos de fósforo, cálcio, magnésio, potássio e, dentre os micronutrientes, principalmente zinco.

Assim, o fornecimento de nutrientes e o balanço nutricional na planta assumem importância fundamental na formação e manutenção dos pastos. O desequilíbrio dos minerais no solo pode interferir na nutrição das plantas e limitar a sua produção.

Desta forma, para se ter forragem adequada aos animais em pastejo é necessário manejar as espécies forrageiras com o emprego de doses e fontes de adubos e forma conveniente de proceder a adubação. O baixo fósforo disponível em solos para a implantação e a manutenção das pastagens nas 
condições brasileiras limita o desenvolvimento do sistema radicular, a produção de massa seca, o perfilhamento e interfere no vigor da forrageira.

Relatos da carência de zinco afetando o desenvolvimento das gramíneas forrageiras são escassos na literatura. Isto se reveste de muita importância principalmente para as regiões de Cerrado brasileiro, onde os solos têm baixa disponibilidade neste nutriente.

Uma interação clássica entre nutrientes é a que ocorre entre o fósforo e o zinco, sendo que a presença de altas concentrações de fósforo nos solos ou nos substratos comprometem o aproveitamento de zinco pelas plantas.

Neste contexto, objetivou-se avaliar as respostas do Panicum maximum cv. Tanzânia, cultivado em solução nutritiva com combinações de doses de fósforo e zinco quanto a: emissão de perfilhos e folhas pelas plantas, valor SPAD, quantidade de clorofila nas plantas, área foliar, produção de massa seca das plantas (parte aérea e raízes), concentrações de fósforo e zinco nas lâminas foliares e comprimento e superfície de raízes. 


\section{REVISÃO DE LITERATURA}

\subsection{Capim-Tanzânia (Panicum maximum cv. Tanzânia)}

O gênero Panicum inclui plantas perenes ou anuais com diversos hábitos de crescimento. Este gênero tem quase 500 espécies, sendo que destas, o número explorado para pastejo é muito pequeno. No Brasil, praticamente só o Panicum maximum tem expressão (Jank, 1994).

O Panicum maximum é uma espécie com hábito de crescimento ereto. Alguns cultivares são tolerantes e outros sensíveis ao encharcamento, enquanto alguns são exigentes em fertilidade do solo e outros são tolerantes ao alumínio. As diferenças nas características genéticas e morfofisiológicas são expressivas no Panicum e devem ser exploradas no processo de utilização e manejo dessa planta forrageira (Corsi,1988).

Como uma forma de introduzir novos cultivares de Panicum maximum na agropecuária do Brasil, a Embrapa Gado de Corte (CNPGC), em conjunto com diversas instituições, realizou pesquisas com uma coleção de acessos oriundos de germoplasma coletado da África pelo Institut Français de Reserche Scientifique Pour Develloppement em Coopération (ORSTOM), objetivando encontrar cultivares adaptados às condições brasileiras e mais produtivos (Jank et al., 1994). Devido ao bom potencial observado para algumas espécies com a realização desse estudo, em 1990 o CNPGC lançou o cultivar Tanzânia-1 de Panicum maximum (Jank, 1994). Este cultivar tem espiguetas com maior quantidade de manchas roxas e um aspecto roxo das inflorescências, bem como apresenta folhas decumbentes e o seu manejo é facilitado pelo fato do seu porte ser pequeno. Por ter abundância de folhas é possível o pastejo do 
capim-Tanzânia, em toda área, sem se acumularem reboleiras rejeitadas pelos animais (Jank, 1995).

\subsection{Fósforo}

O fósforo é exigido em menor quantidade que o nitrogênio e o potássio pelas plantas, porém trata-se do nutriente mais usado em adubação no Brasil. Isso se explica pela baixa disponibilidade deste elemento nos solos brasileiros e pela forte interação entre partículas do solo e o íon fosfato, que reduz a disponibilidade de fósforo para ser absorvido pelas plantas. O fósforo é encontrado na solução do solo como íon ortofosfato $\left(\mathrm{H}_{2} \mathrm{PO}_{4}{ }^{-}\right)$, sendo que a predominância desta forma é dependente do $\mathrm{pH}$ do meio. Diversos minerais e compostos são fontes de fósforo para os solos, entre os quais estão: estrengita, variscita, hidroxiapatita e fluorapatita (Raij, 1991).

A baixa disponibilidade de fósforo compromete não apenas o estabelecimento das plantas forrageiras, como também afeta sua produtividade e valor nutritivo, prejudicando o desempenho animal. A carência de fósforo causa distúrbios imediatos e severos no metabolismo e desenvolvimento das plantas e geralmente reduz o perfilhamento, retarda o desenvolvimento das gramíneas forrageiras e permite a ocupação do pasto por espécies invasoras (Werner, 1986). O fósforo é um macronutriente, porém sua concentração nas plantas é baixa, com valores que raramente ultrapassam $5 \mathrm{~g} \mathrm{~kg} \mathrm{~kg}^{-1}$. Concentrações mais elevadas ocorrem somente em culturas que têm na semente a parte mais importante na colheita (Raij, 1991).

\subsubsection{Respostas de gramíneas forrageiras à adubação fosfatada}

As recomendações de adubação fosfatada para as pastagens têm se baseado nos teores de fósforo obtidos nas análises de terra. Para Panicum maximum as quantidades de $\mathrm{P}_{2} \mathrm{O}_{5}$ (na forma prontamente solúvel em água) oscilam entre 30 e $100 \mathrm{~kg} \mathrm{ha}^{-1}$ para a formação de pastagens, e entre 20 e 60 $\mathrm{kg} \mathrm{ha}^{-1}$ para pastagens já estabelecidas (Monteiro, 1995). 
Melo (2005), trabalhando com a forrageira Brachiaria brizantha cv. Marandu, adicionando doses de fósforo de 10 a $330 \mathrm{mg} \mathrm{dm}^{-3}$ num experimento em casa-de-vegetação, verificou incrementos na produção de massa seca, área foliar, número de folhas e perfilhos do capim, em função das doses de fósforo aplicado ao Latossolo Vermelho-Amarelo distrófico.

Magalhães et al. (2004) realizaram experimento em solos classificados como Mollisols, Argiustolls (Brunizens) no período das águas, aplicando doses de nitrogênio (0;100; 200 e $\left.300 \mathrm{~kg} \mathrm{ha}^{-1} \mathrm{ano}^{-1}\right)$ e de fósforo (0; 50 e $100 \mathrm{~kg} \mathrm{ha}^{-1} \mathrm{ano}^{-1}$ ) para o capim-Braquiária (Brachiaria decumbens). Verificaram ajustes lineares para a produção de massa seca da parte aérea da forrageira em função das doses de fósforo adicionadas ao solo.

Em experimento em casa-de-vegetação, Oliveira et al. (2004) avaliaram o efeito da adubação fosfatada e regimes de corte para o capim-deraiz (Choris orthonoton). As doses de fósforo $\left(\mathrm{P}_{2} \mathrm{O}_{5}\right)$ utilizadas foram de $0,100 \mathrm{e}$ $200 \mathrm{~kg} \mathrm{ha}^{-1}$, com duas freqüências de corte (30 e 40 dias) e duas intensidades de corte (5 e $15 \mathrm{~cm}$ ). Observaram que na não aplicação de fósforo ao solo, a produção de forragem foi significativamente menor que a obtida nas doses de 100 e $200 \mathrm{~kg} \mathrm{ha}^{-1}$.

Mesquita et al. (2004) trabalharam num experimento em casa-devegetação, avaliando a aplicação de fósforo em três solos para o capimMarandu, capim-Mombaça (Panicum maximum) e capim-Andropogon (Andropogon gayanus). As doses aplicadas no Latossolo Vermelho-Amarelo distroférrico e no Latossolo Vermelho distroférrico foram de 0, 110, 220, 330 e $560 \mathrm{mg} \mathrm{dm}^{-3}$ e no Neossolo Quartzarênico foram de 0, 80, 160, 240 e 410

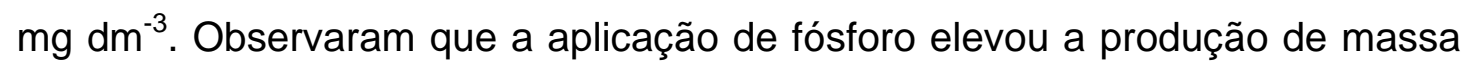
seca da parte aérea e das raízes, e o número de perfilhos das forrageiras nos três solos estudados.

Maique \& Monteiro (2003) estudaram doses de $0 ; 0,2 ; 1 ; 5 ; 10 ; 20 ; 30$ e $40 \mathrm{mg} \mathrm{L}^{-1}$ para o capim-Mombaça em solução nutritiva em casa-de-vegetação. Verificaram que a distribuição e a recuperação do fósforo foram influenciadas 
pelo aumento da disponibilidade do nutriente. Os resultados mostraram que cerca de 50\% do fósforo encontrado nas plantas está presente nas partes mais novas, como folhas em expansão e folhas recém-expandidas. Quanto à recuperação do fósforo, relataram que cerca de um terço da quantidade de fósforo disponibilizado na solução estava na parte aérea do capim.

O aumento na produção de massa seca da parte aérea do capimTanzânia (Panicum maximum) em função das doses de fósforo ( $P=0$ a 140 $\mathrm{mg} \mathrm{dm}^{-3}$ ) aplicadas aos solos arenoso, de textura média e argiloso, em um experimento conduzido em casa-de-vegetação, foi relatado por Gheri et al. (2000). O maior acréscimo de produção de massa seca foi verificado com o emprego da dose de $35 \mathrm{mg} \mathrm{dm}^{-3}$, independente do tipo de solo. As concentrações médias de fósforo nas plantas variaram para solos de textura arenosa de 0,95 a 1,21 $\mathrm{g} \mathrm{kg}^{-1}$ no primeiro corte e de 0,84 a 1,00 g kg-1 no segundo corte, da menor para a maior dose. Para os solos de textura média variaram de 1,18 a $0,95 \mathrm{~g} \mathrm{~kg}^{-1}$ no primeiro corte e de 0,98 a $0,79^{-1}$ no segundo corte. Já para o solo argiloso a concentração de fósforo foi de 1,17 a 1,39 g kg no primeiro corte e de 0,84 a $1,17 \mathrm{~g} \mathrm{~kg}^{-1}$ no segundo corte.

Brito Filho et al. (1999) aplicaram doses de nitrogênio (0, 200, 400 e $600 \mathrm{~kg} \mathrm{ha}^{-1} \mathrm{ano}^{-1}$ ) e fósforo (0, 50, 100, 150 e $200 \mathrm{~kg} \mathrm{ha}^{-1} \mathrm{ano}^{-1}$ ) em um Podzólico Vermelho Amarelo Distrófico, em área com capim-Marandu. Concluiram que o nitrogênio e o fósforo apresentaram efeitos significativos no número total de perfilhos, número de perfilhos vivos e número de perfilhos decapitados. Dentro das doses de nitrogênio, o fósforo apresentou comportamento linear para o perfilhamento da forrageira.

Em experimento em casa-de-vegetação, com capim-Colonião (Panicum maximum) em solução nutritiva, utilizando três doses de fósforo $(3,1$; 15,5 e 31,0 $\mathrm{mg} \mathrm{L}^{-1}$ ) e dez épocas de colheita, Rossi (1999) verificou expressivos incrementos na produção da parte aérea e de raízes, em função das doses de fósforo, já a partir das primeiras épocas de colheita. Esta constatação confirmou 
que esse capim necessita de bom suprimento de fósforo para atender o seu crescimento rápido nas fases iniciais de desenvolvimento (Werner, 1986).

As influências do fósforo na produção de massa seca das plantas e no perfilhamento foram constatadas por Almeida (1998), em experimento utilizando solução nutritiva com doses de fósforo de 3,1; 15,5 e $31 \mathrm{mg} \mathrm{L}^{-1}$ e doses de magnésio de 4,8; 24; 48 e $72 \mathrm{mg} \mathrm{L}^{-1}$. Obteve ajuste linear para a produção de massa seca com o incremento de fósforo para a Brachiaria decumbens e um ajuste quadrático para a Brachiaria brizantha. O aumento das doses de fósforo estimulou o perfilhamento das duas forrageiras, já na fase de estabelecimento.

Corrêa \& Freitas (1997) testaram doses de fósforo no capimTanzânia, num Latossolo Vermelho Amarelo Álico, aplicando doses de $\mathrm{P}_{2} \mathrm{O}_{5}$ de $0,50,100,200,400$ e $800 \mathrm{~kg} \mathrm{ha-1}$. Encontraram variações positivas na produção de massa seca e no fósforo extraído pelas plantas, em função das quantidades aplicadas.

Rupin (1997) conduziu um experimento com capim-Elefante (Pennisetum purpureum), avaliando formas de aplicação e doses de fósforo. Concluiu que a concentração de fósforo na parte aérea diminuiu do primeiro para o segundo corte, independentemente da forma de aplicação, enquanto no solo isso só ocorreu com o nutriente aplicado de forma localizada. Observou ainda que maiores valores de níveis críticos no capim foram obtidos quando o fósforo foi aplicado de forma distribuída no sulco.

Corrêa et al. (1996), avaliando quatro cultivares de Panicum maximum (Tanzânia, Mombaça, Vencedor e T21) e seis doses de $\mathrm{P}_{2} \mathrm{O}_{5}(0,50$, 100, 200, 400 e $800 \mathrm{~kg} \mathrm{ha}^{-1}$ ) na forma de superfosfato triplo granulado, observaram que os cultivares responderam igualmente à adubação fosfatada, aumentando de forma significativa a produção de massa seca. As concentrações de fósforo nas folhas dos capins aumentaram significativamente com as doses do nutriente. Os níveis críticos de fósforo no solo e na planta para 
atingir $80 \%$ da produção máxima foram $21 \mathrm{mg} \mathrm{dm}$ e $2,3 \mathrm{~g} \mathrm{~kg}^{-1}$, respectivamente.

Hoffmann et al. (1995), observando respostas do capim-Colonião a doses de fósforo, concluíram que a omissão de fósforo reduziu a produção de massa seca do capim em relação ao tratamento completo. Para o nível crítico de fósforo na planta concluíram que no primeiro crescimento foi de $2,4 \mathrm{~g} \mathrm{~kg}^{-1}$ enquanto no segundo foi de $1,8 \mathrm{~g} \mathrm{~kg}^{-1}$.

Corrêa (1991) trabalhou com três espécies de forrageiras em casade-vegetação variando doses de fósforo $\left(\mathrm{P}_{2} \mathrm{O}_{5}\right)$ de 0 a $560 \mathrm{mg} \mathrm{kg}{ }^{-1}$. Obteve respostas positivas para os três capins, com o incremento de fósforo, sendo observado aumento de produção de massa seca até a dose $\mathrm{P}_{2} \mathrm{O}_{5}$ de 140 $\mathrm{mg} \mathrm{kg}{ }^{-1}$. Verificou que, na ausência de adubação fosfatada, o perfilhamento foi reduzido para as três espécies forrageiras, nos dois cortes de avaliação.

Meirelles et al. (1988), estudando doses de fósforo $\left(\mathrm{P}_{2} \mathrm{O}_{5}\right)$ de 0, 25, $50,75,100,200$ e $400 \mathrm{~kg} \mathrm{ha}^{-1}$ no capim-Colonião, em um Latossolo VermelhoEscuro álico e num Podzólico Vermelho Amarelo distrófico, observaram que o número de perfilhos e a produção de massa seca aumentaram significativamente com o incremento das doses de fósforo nos dois solos. Para o nível crítico de fósforo no capim, encontraram valores entre 1,68 e 1,96 g kg-1, nos dois solos estudados.

\subsection{Zinco}

O zinco é um micronutriente absorvido na forma $\mathrm{Zn}^{+2}$ e a absorção radicular ou foliar se dá ativamente. É um elemento pouco móvel na planta e sua deficiência pode ser visualmente constatada pelo encurtamento dos internódios, clorose em folhas novas, deformação nas folhas (a chamada "folha pequena") sendo este um sintoma típico e que pode ser usado para diferenciar da deficiência de ferro. Por ser um micronutriente imóvel, os sintomas aparecem primeiro nas folhas mais novas (Romheld, 2001). 
As funções mais conhecidas do zinco nas plantas são: participação na síntese do AIA (ácido indolacético); importante para o RNA, pois inibe a RNAse que hidrolisa o RNA; redução de nitrato a nitrito, oxidases e outras (Malavolta et al., 1997). A sua disponibilidade é afetada pelo $\mathrm{pH}$ e a elevação do $\mathrm{pH}$ do solo (pela calagem) pode induzir sua deficiência (Raij, 1991).

Em folhas, o nível crítico de zinco está entre 15 e $20 \mathrm{mg} \mathrm{kg}^{-1}$ de massa seca. As espécies se diferenciam na sensibilidade para deficiência de zinco, sendo que o milho (Zea mays) e o algodão (Gossypium hirsutum) são mais sensíveis que, por exemplo, o trigo (Triticum aestivum) e a aveia (Avena sp.) (Marschener, 1995).

Fageria \& Stone (2004) verificaram que o feijão (Phaseolus vulgaris) não apresentou respostas significativas a doses de zinco de 0, 5, 10, 20, 40 e $80 \mathrm{~kg} \mathrm{ha}^{-1}$ aplicadas num solo argiloso de cerrado, sob o sistema de plantio direto.

André et al. (2003) realizaram experimento em casa-de-vegetação, aplicando doses de zinco de 0; 2,5; 5,0; 7,5 e $10 \mathrm{mg} \mathrm{dm}^{-3}$ de início somente no solo e depois de fazer as análises, cultivaram o Tifton-85 (Cynodon spp) para determinar a concentração foliar. Observaram que as relações entre as características estudadas mostraram que tanto o Zn-DTPA quanto o Zntrocável, ligado à matéria orgânica e aos óxidos de $\mathrm{Mn}$, foram eficientes para representar o zinco absorvido pela planta. Os resultados de concentrações de zinco nas plantas ajustaram-se ao modelo quadrático de regressão em função do zinco presente no solo.

Fageria (2000) utilizou-se de um Latossolo Vermelho-Escuro textura franco-argilosa para conduzir cinco experimentos em casa-de-vegetação aplicando doses de zinco de 0, 5, 10, 20 40, 80 e $120 \mathrm{mg} \mathrm{kg}^{-1}$ de solo para as culturas de arroz (Oryza sativa), feijão, milho, soja (Glycine sp.) e trigo. Verificou que as produções de massa seca da parte aérea e das raízes das plantas foram influenciadas pelas doses de zinco, com exceção do feijão. Observou ainda que para o arroz, a dose adequada de zinco no solo foi de $10 \mathrm{mg} \mathrm{kg}^{-1} \mathrm{e}$ 
para o milho de $3 \mathrm{mg} \mathrm{kg}^{-1}$, sendo estas culturas as mais sensíveis à deficiência de zinco. Nas folhas, o nível adequado de zinco foi de $67 \mathrm{mg} \mathrm{kg}^{-1}$ para a cultura de arroz e de $27 \mathrm{mg} \mathrm{kg}^{-1}$ para o milho.

Em Planaltina, Galrão (1995) realizou experimento num Latossolo Vermelho-Amarelo argiloso, avaliando respostas do milho a doses de zinco e calcário. Foram aplicadas quatro doses de zinco (0,0, 1,0, 3,0 e 9,0 kg ha-1) e calcário para a saturação por bases de 30, 50 e 70\%. Os aumentos nas doses de zinco influenciaram positivamente o rendimento dos grãos, os teores de zinco extraídos do solo e as concentrações de zinco nas folhas. O nível crítico de zinco nas folhas foi de $18,5 \mathrm{mg} \mathrm{kg}^{-1}$.

Melo et al. (1992) aplicaram zinco na forma inorgânica e nas doses de 0, 3, 6 e $9 \mathrm{~kg} \mathrm{ha}^{-1}$, em um Cambissolo de textura argilosa na qual cultivaram o feijoeiro. Verificaram que os teores de zinco disponível no solo aumentaram proporcionalmente com as doses aplicadas na forma inorgânica. Observaram que as concentrações de zinco nas folhas de feijão apresentaram a maior média para o tratamento residual de $9 \mathrm{~kg} \mathrm{ha}^{-1}$ e variaram de 24,0 a 45,3 $\mathrm{mg} \mathrm{kg}^{-1}$.

Em experimento, testando doses de zinco de 0, 1,0, 2,0, 3,0 e 4,0 $\mathrm{mg} \mathrm{kg}^{-1}$ e três níveis de correção do solo, em um Latossolo Vermelho-Escuro, Buzetti et al. (1991) estudaram a nutrição em zinco da soja. Nos tratamentos que receberam corretivos, observaram que as doses de zinco exerceram efeito positivo tanto na produção de massa seca da parte aérea como nos grãos. Constataram uma relação linear entre os teores de zinco no solo e as doses de zinco aplicadas.

Cakmak et al. (1989), estudando a nutrição de plantas de feijão, verificaram que plantas deficientes em zinco apresentaram redução no crescimento, diminuição da concentração de proteínas solúveis, de clorofila e diminuição na concentração do ácido indolacético.

Em experimento em casa-de-vegetação, Galrão \& Mesquita Filho (1981a) testaram cinco doses de zinco de 0,0, 1,25, 2,50, 5,00 e 10,0 $\mathrm{mg} \mathrm{dm}^{-3}$, 
três fontes (sulfato, óxido e fritas) e duas doses de calcário num Latossolo Vermelho-Amarelo de textura argilosa, verificando que a menor doses de zinco foi a que resultou na menor produção massa seca e diferiu significativamente das demais. Observaram ainda que o calcário causou aumento na produção de massa seca e diminuição na absorção de zinco pelo milho.

Galrão \& Mesquita Filho (1981b) realizaram um experimento em campo, buscando avaliar o efeito de micronutrientes no rendimento e na composição química do arroz e do milho, num Latossolo Vermelho-Escuro, textura argilosa. Utilizaram tratamentos com omissões individuais de boro, cobalto, cobre, ferro, manganês, molibdênio e zinco. Concluíram que apenas a omissão do zinco resultou em decréscimo na produção nessas culturas.

Plantas de algodão foram colocadas para crescer em casa-devegetação, em soluções nutritivas que continham quantidades de zinco de 10 , 20, 50, 100, 200, 1000 e $2000 \mu \mathrm{g} \mathrm{L}^{-1}$ e as aplicações foram realizadas aos 14 , 21 e 28 dias após o transplante. A redução no suprimento de zinco causou diminuição da fotossíntese, redução da atividade da anidrase carbônica e da concentração de clorofila (Ohki, 1976).

Salami \& Kenefick (1970), trabalhando com plântulas de milho, observaram que a adição de triptofano em plantas deficientes em zinco resultou em aumento na produção da parte aérea.

Bar-Akiva \& Lavon (1969), estudando a deficiência de zinco em plantas de citros (Citrus sp.), num experimento realizado em casa-de-vegetação com solução nutritiva contendo ou não zinco, concluíram que a anidrase carbônica foi utilizada como um indicador da deficiência de zinco e teve baixa atividade nesta situação.

\subsection{Relação entre fósforo e zinco}

É clássica na literatura a descrição da deficiência de zinco induzida pelo fósforo: altas concentrações de fósforo no solo ou solução nutritiva causam diminuição na disponibilidade de zinco. Isso pode ocorrer, pois o fósforo 
insolubiliza o zinco na superfície das raízes diminuindo sua absorção (Malavolta et al., 1997) ou o fósforo precipita o zinco como fosfato de zinco, impedindo a absorção pelas plantas (Marschner, 1995). Poucas referências são encontradas para a interação fósforo e zinco nas plantas e, em forrageiras os trabalhos científicos são ainda mais escassos.

Buscando avaliar o efeito do fósforo e do zinco nas mudas de aceroleira (Malpighia glabra), Corrêa et al. (2002) desenvolveram experimento em casa-de-vegetação, aplicando doses de fósforo (0; 150; 300 e $450 \mathrm{mg} \mathrm{dm}^{-3}$ de solo) e doses de zinco (0;5 e $10 \mathrm{mg} \mathrm{dm}^{-3}$ de solo) num Latossolo. Verificaram que a dose de fósforo de $450 \mathrm{mg} \mathrm{dm}^{-3}$ combinada com a não aplicação de zinco foram as que proporcionaram maior altura das plantas.

Em cultivo de alface (Lactuca sativa), Moreira et al. (2001) aplicaram doses de fósforo $\left(0,01,1,5\right.$ e $\left.6,0 \mathrm{mmol} \mathrm{L}^{-1}\right)$ e zinco $\left(0,0,1,5\right.$ e $\left.6,0 \mathrm{~mol} \mathrm{~L}^{-1}\right)$, com objetivo de avaliar a absorção destes nutrientes pelas plantas e a produção da hortaliça. Verificaram que nas doses mais baixas de fósforo, o efeito do zinco não foi significativo, mas nas demais doses de fósforo, as doses de zinco de 1,5 e $6,0 \mathrm{mmol} \mathrm{L}^{-1}$ propiciaram maior área foliar, maior número de folhas e maior produção da parte aérea de alface. Não ocorreram diferenças nas concentrações de fósforo nas folhas diagnósticas quando comparadas as doses 1,5 e de $6,0 \mathrm{mmol} \mathrm{L}^{-1}$. A maior concentração de fósforo foi no caule, seguida das raízes, e, por último, das folhas. Quanto às concentrações de zinco na massa seca das folhas, dos caules e das raízes houve aumento com a adição de desse micronutriente na solução, em todas as doses de fósforo.

Hernándes \& Cardenas (1990), em experimento de campo num solo que continha inicialmente $\mathrm{P}_{2} \mathrm{O}_{5}$ de $22,8 \mathrm{mg} \mathrm{L}^{-1}$, verificaram que não era necessário aplicar fósforo, pelo menos durante os dois primeiros anos de crescimento do Panicum maximum cv. Likoni. Nos tratamentos com fósforo e fósforo+zinco não encontraram diferenças em relação à testemunha, quando avaliaram a produção de massa seca, a altura do pasto e a concentração de fósforo na planta. 
Webb \& Loneragan (1988), estudando em trigo a relação entre fósforo e zinco, verificaram que em plantas deficientes em zinco existe maior concentração de fósforo nas folhas velhas, que chegam a necrosar devido a toxidez desse elemento. Também Loneragan et al. (1982), trabalhando com quiabo (Abelmoschus esculentus) em solução nutritiva e estudando a relação entre o fósforo e zinco concluiram que na deficiência de zinco ocorreu maior acúmulo de fósforo nas folhas velhas da planta, causando toxidez desse nutriente mostrada por necrose internerval nessas folhas.

Fancelli (1986), abordando a interação entre fósforo e zinco em sorgo (Sorghum bicolor), verificou maiores produtividades de panículas e grãos quando adicionou zinco juntamente com o fósforo. Também afirmou que a melhor qualidade fisiológica das sementes de sorgo dependeu das adições de zinco e de fósforo em proporções equilibradas.

Muner (1986), efetuando adubação localizada de fósforo no solo juntamente com a fertilização com zinco, constatou que mediante aplicação de zinco, o emprego mais localizado do fósforo resultou em aumento da produção de massa seca e em redução na concentração de zinco na planta.

Souza et al. (1985), estudando doses de fósforo (50, 100, 150 e 200 $\left.\mathrm{kg} \mathrm{ha}^{-1}\right)$ e de zinco $\left(0,25,50,75\right.$ e $\left.100 \mathrm{~kg} \mathrm{ha}^{-1}\right)$ em plantas de milho, concluíram que as concentrações foliares de fósforo e zinco não são indicativos seguros para predizer as maiores produções de milho em grãos e afirmaram que a dose econômica de $\mathrm{P}_{2} \mathrm{O}_{5}$ a ser aplicada na semeadura, em solo com baixo fósforo disponível é de $149 \mathrm{~kg} \mathrm{ha}^{-1}$ acompanhada de sulfato de zinco na dose de $25 \mathrm{~kg}$ $\mathrm{ha}^{-1}$.

Orabi \& Abdel-Aziz (1982), trabalhando com milho em um solo calcário do Egito, aplicaram doses de sulfato de zinco de 25, 50 e $100 \mathrm{~kg} \mathrm{ha}^{-1} \mathrm{e}$ de $\mathrm{P}_{2} \mathrm{O}_{5}$ de 75,$5 ; 112,5$ e $187,5 \mathrm{~kg} \mathrm{ha}^{-1}$ em tratamentos contendo esses nutrientes separados e combinados. Observaram que quando fósforo e zinco são aplicados combinados, ocorre uma produção maior ou igual àquela obtida quando se aplicam os nutrientes separados. 
Lopez-Gorostiaga (1972) verificou que a concentração de zinco nas plantas diminuiu com a adição de adubo fosfatado no solo, enquanto a disponibilidade de zinco no solo não foi influenciada pela adubação com fósforo.

Pauli et al. (1968) testaram a relação entre fósforo e zinco nos tecidos de plantas de feijão crescido em solução nutritiva e concluíram que altas doses de fósforo resultaram em aumento na concentração de zinco em toda a parte da planta. Isto está em desacordo com outros trabalhos de pesquisa, em que o fósforo induz a deficiência de zinco.

Em experimentos realizados em campo e em casa-de-vegetação por Boawn \& Leggett (1964), foi estudada a interação entre fósforo e zinco em batata (Solanum tuberosum). Concluíram que existe um antagonismo mútuo entre o fósforo e o zinco, principalmente quando um desses elementos excede o nível crítico. As plantas que tiveram crescimento anormal foram as que não possuiam balanço adequado de fósforo e zinco. 


\section{MATERIAL E MÉTODOS}

\subsection{Local, época e espécie forrageira}

O experimento foi realizado numa casa-de-vegetação localizada no Departamento de Solos e Nutrição de Plantas da Escola Superior de Agricultura "Luiz de Queiroz" - USP, Campus Piracicaba, Estado de São Paulo, com a forrageira Panicum maximum cultivar Tanzânia, de 19 de janeiro a 19 de março de 2004.

\subsection{Doses de fósforo e de zinco e delineamento experimental}

Utilizou-se a solução nutritiva completa proposta por Sarruge (1975) modificando-a para as doses de fósforo e zinco, visando obter para o fósforo as concentrações de 0,$2 ; 0,6 ; 1,0 ; 1,4$ e $1,8 \mathrm{mmol} \mathrm{L}^{-1}$ e para o zinco as de 0,0 ; 0,$25 ; 0,50 ; 0,75$ e $1,00 \mu \mathrm{mol} L^{-1}$. O estudo foi em superfície de resposta, baseado no desenho experimental composto central modificado de um esquema fatorial $5^{2}$ incompleto (Littell \& Mott, 1975). De acordo com esse desenho formaram-se 13 combinações, assim definidas, para fósforo $\left(\mathrm{mmol} \mathrm{L}^{-1}\right)$ e zinco $\left(\mu \mathrm{mol} \mathrm{L}^{-1}\right.$ ) respectivamente: 0,2-0,0; 0,2-0,50; 0,2-1,0; 0,6-0,25; 0,6-0,75; $1,0-0,0 ; 1,0-0,50 ; 1,0-1,00 ; 1,4-0,25 ; 1,4-0,75 ; 1,8-0,0 ; 1,8-0,50$ e $1,8-1,00$. Os vasos foram distribuídos segundo o delineamento de blocos ao acaso, com quatro repetições. $O$ nitrogênio foi fornecido na dose de $30 \mathrm{mmol} \mathrm{L}^{-1}$, com o objetivo de bem explorar o potencial produtivo da forrageira. Os demais 
nutrientes foram mantidos nas concentrações originais da solução de Sarruge (1975) conforme apresentado na Tabela 1.

Tabela 1. Volume da solução estoque utilizadas nas soluções nutritivas, em função das doses de fósforo e zinco ${ }^{(1)}$

\begin{tabular}{|c|c|c|c|c|c|c|c|c|c|c|c|c|c|}
\hline \multirow{2}{*}{ Solução estoque } & $\begin{array}{l}0,2- \\
0,00\end{array}$ & $\begin{array}{l}0,2- \\
0,50\end{array}$ & $\begin{array}{l}0,2- \\
1,00\end{array}$ & $\begin{array}{l}0,6- \\
0,25\end{array}$ & $\begin{array}{l}0,6- \\
0,75\end{array}$ & $\begin{array}{l}1,0- \\
0,00\end{array}$ & $\begin{array}{l}1,0- \\
0,50\end{array}$ & $\begin{array}{l}1,0- \\
1,00\end{array}$ & $\begin{array}{l}1,4- \\
0,25\end{array}$ & $\begin{array}{l}1,4- \\
0,75\end{array}$ & $\begin{array}{l}1,8- \\
0,00\end{array}$ & $\begin{array}{l}1,8- \\
0,50\end{array}$ & $\begin{array}{l}1,8- \\
1,00\end{array}$ \\
\hline & & & & & & & & & & & & & \\
\hline $\mathrm{KH}_{2} \mathrm{PO}_{4} \mathrm{~mol} \mathrm{~L}^{-1}$ & 0,2 & 0,2 & 0,2 & 0,6 & 0,6 & 1,0 & 1,0 & 1,0 & 1,0 & 1,0 & 1,0 & 1,0 & 1,0 \\
\hline $\mathrm{KCl} \mathrm{mol} \mathrm{L}^{-1}$ & 0,8 & 0,8 & 0,8 & 0,4 & 0,4 & 0,0 & 0,0 & 0,0 & 0,0 & 0,0 & 0,0 & 0,0 & 0,0 \\
\hline $\mathrm{KNO}_{3} \mathrm{~mol} \mathrm{~L}^{-1}$ & 5,0 & 5,0 & 5,0 & 5,0 & 5,0 & 5,0 & 5,0 & 5,0 & 5,0 & 5,0 & 5,0 & 5,0 & 5,0 \\
\hline $\mathrm{Ca}\left(\mathrm{NO}_{3}\right)_{2} \mathrm{~mol} \mathrm{~L}^{-1}$ & 5,0 & 5,0 & 5,0 & 5,0 & 5,0 & 5,0 & 5,0 & 5,0 & 5,0 & 5,0 & 5,0 & 5,0 & 5,0 \\
\hline $\mathrm{MgSO}_{4} \mathrm{~mol} \mathrm{~L}^{-1}$ & 2,0 & 2,0 & 2,0 & 2,0 & 2,0 & 2,0 & 2,0 & 2,0 & 2,0 & 2,0 & 2,0 & 2,0 & 2,0 \\
\hline $\mathrm{NH}_{4} \mathrm{NO}_{3} \mathrm{~mol} \mathrm{~L}^{-1}$ & 7,5 & 7,5 & 7,5 & 7,5 & 7,5 & 7,5 & 7,5 & 7,5 & 7,5 & 7,5 & 7,5 & 7,5 & 7,5 \\
\hline MICRO -Zn ${ }^{(2)}$ & 1,0 & 1,0 & 1,0 & 1,0 & 1,0 & 1,0 & 1,0 & 1,0 & 1,0 & 1,0 & 1,0 & 1,0 & 1,0 \\
\hline Fe-EDTA $^{(3)}$ & 1,0 & 1,0 & 1,0 & 1,0 & 1,0 & 1,0 & 1,0 & 1,0 & 1,0 & 1,0 & 1,0 & 1,0 & 1,0 \\
\hline $\mathrm{NaH}_{2} \mathrm{PO}_{4}$ & - & - & - & - & - & - & - & - & 0,4 & 0,4 & 0,8 & 0,8 & 0,8 \\
\hline $\mathrm{ZnCl}_{2}{ }^{(4)}$ & - & 0,5 & 1,0 & 1,0 & 0,75 & - & 0,5 & 1,0 & 1 & 0,75 & - & 0,5 & 1,0 \\
\hline
\end{tabular}

${ }^{1}$ Concentração de macronutrientes na solução nutritiva: $\mathrm{N}\left(420 \mathrm{mg} \mathrm{L}^{-1}\right) ; \mathrm{K}(234$ $\left.\mathrm{mg} \mathrm{L})^{1}\right) ; \mathrm{Ca}\left(200 \mathrm{mg} \mathrm{L}^{-1}\right) ; \mathrm{Mg}\left(48 \mathrm{mg} \mathrm{L}^{-1}\right)$ e $\mathrm{S}\left(64 \mathrm{mg} \mathrm{L}^{-1}\right)$.

${ }^{2}$ Composição da solução de micronutrientes menos zinco: $\mathrm{H}_{3} \mathrm{BO}_{3}\left(2,86 \mathrm{~g} \mathrm{~L}^{-1}\right)$; $\mathrm{MnCl}_{2} \cdot 4 \mathrm{H}_{2} \mathrm{O}\left(1,81 \mathrm{~g} \mathrm{~L}^{-1}\right) ; \mathrm{CuCl}_{2}\left(0,04 \mathrm{~g} \mathrm{~L}^{-1}\right)$ e $\mathrm{H}_{2} \mathrm{MoO}_{4} \cdot \mathrm{H}_{2} \mathrm{O}\left(0,02 \mathrm{~g} \mathrm{~L}^{-1}\right)$.

${ }^{3}$ Procedimento para preparação de 1 litro da solução de Fe-EDTA: Dissolveramse $26,2 \mathrm{~g}$ de EDTA dissódico em $286 \mathrm{~mL}$ de $\mathrm{NaOH}\left(\mathrm{mol} \mathrm{L}^{-1}\right)$ e misturaram-se $24,0 \mathrm{~g}$ de $\mathrm{FeSO}_{4} \cdot 7 \mathrm{H}_{2} \mathrm{O}$. Arejou-se por uma noite e completou-se o volume com água desionizada.

${ }^{4}$ Preparada com $\mathrm{ZnCl}_{2} 0,136 \mathrm{~g} \mathrm{~L}^{-1}$. 


\subsection{Condução do experimento}

A germinação das sementes e crescimento inicial das mudas foram realizados em bandejas plásticas, contendo areia lavada em água corrente e em água desionizada, no período de 07 de janeiro a 19 de janeiro de 2004. O transplante de 15 mudas para os vasos foi efetuado quando as plântulas atingiram aproximadamente $4 \mathrm{~cm}$ de altura.

Utilizaram-se vasos plásticos com capacidade de 3,6 L tendo sílica como substrato, sendo esta lavada (para eliminar os resíduos) em água corrente e posteriormente com água desionizada.

Após o transplante das mudas para os vasos, foi fornecida uma solução diluída a um quarto da concentração total correspondente a cada combinação estudada, durante um período de cinco dias, após o que a solução definitiva foi adicionada. Os desbastes ocorreram periodicamente até permanecerem cinco plantas por vaso.

As soluções foram circuladas três vezes ao dia para que ocorresse a oxigenação das raízes, e foram drenadas no início da noite. A renovação das soluções deu-se a cada 14 dias, a partir de sua adição nos vasos.

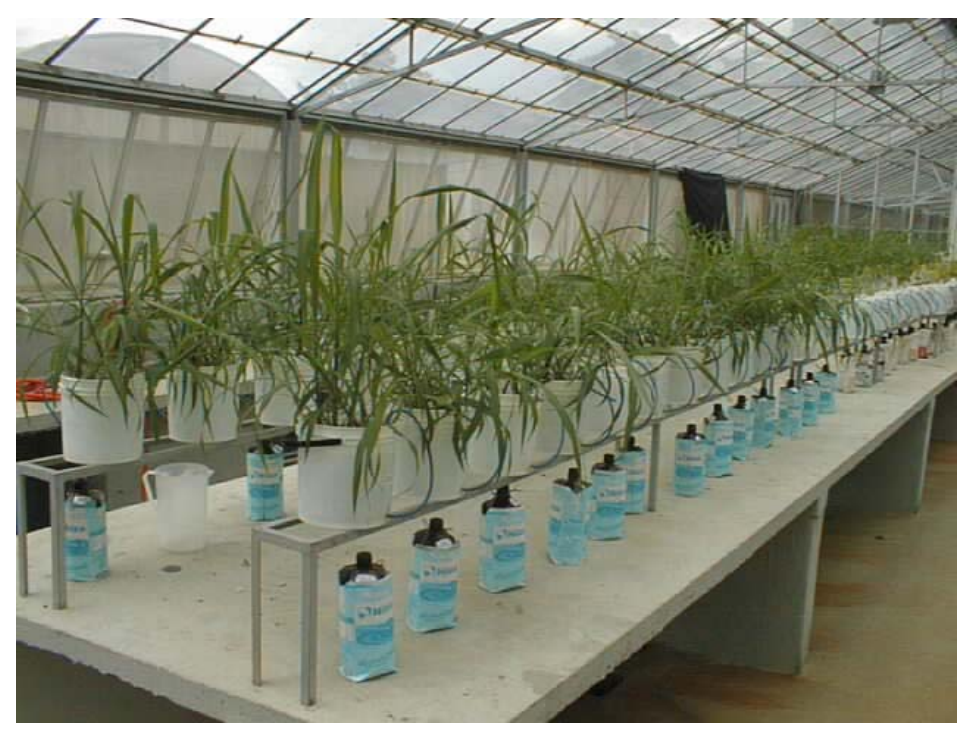

Figura 1 - Vista geral do experimento 


\subsection{Emissão de perfilhos e de folhas}

Os números de perfilhos e folhas foram contados a cada três dias durante o crescimento das plantas. No final de cada período de crescimento foram somados os números das contagens individuais, obtendo-se o total de folhas e de perfilhos. Os perfilhos novos eram marcados com fios de plástico e as folhas que apresentavam lígula visível foram marcadas com caneta para transparências.

\subsection{Valor SPAD}

Para a estimativa do teor de clorofila, avaliada em unidades SPAD, utilizou-se o clorofilômetro SPAD-502 (Soil-Plant Analysis Development Section, Minolta Camera Co., Osaka, Japan).

As leituras no clorofilômetro foram realizadas no dia em que realizou-se o primeiro corte, e aos 22 dias do segundo crescimento, no terço médio da lâmina da segunda folha completamente expandida a partir do ápice de cada planta. Efetuou-se a leitura em 10 folhas e obteve-se a média desses valores para cada vaso.

\subsection{Coleta do material vegetal}

Foram realizados dois cortes das plantas, sendo o primeiro aos 32 dias após o transplante das mudas e o segundo aos 28 dias após o primeiro corte. A parte aérea das plantas foi separada em: a) folhas emergentes (FE), ou seja, as folhas não completamente expandidas; b) lâminas de folhas recém-expandidas (LR), sendo aquelas lâminas das duas folhas mais jovens totalmente expandidas c) lâminas de folhas maduras (LM), ou seja, as lâminas das demais folhas totalmente expandidas e d) colmos + bainhas (CB) correspondentes aos colmos propriamente ditos $\mathrm{e}$ as bainhas que foram mantidas a eles 
circundadas. Após o segundo corte da parte aérea, as raízes foram separadas e lavadas em água corrente e desionizada. O material colhido foi secado por 72 horas em estufa de circulação forçada de ar a $70^{\circ} \mathrm{C}$, com posterior pesagem e moagem em moinho do tipo Wiley, com a colocação das amostras moídas em sacos plásticos para as análises laboratoriais.

\subsection{Determinação da área foliar}

A determinação da área foliar foi realizada em cada tipo de tecido foliar (FE, LR e LM) e a área foliar total foi obtida pela soma desses valores. Essa medida foi realizada pelo aparelho integrador de área foliar LICOR LI-3000 imediatamente após cada corte das plantas, com as lâminas foliares ainda verdes.

\subsection{Produção de massa seca}

Os valores obtidos na pesagem dos componentes da parte aérea (folhas emergentes, lâminas de folhas recém-expandidas, lâminas de folhas maduras e colmos mais bainhas) foram reunidos para a computação da produção da parte aérea total em ambos os cortes das plantas. Para a massa seca de raízes, as mesmas foram pesadas para a obtenção desses valores.

\subsection{Composição mineral do tecido vegetal}

Foram determinadas as concentrações de fósforo e zinco conforme metodologia descrita por Sarruge \& Haag (1974). Realizou-se a digestão nítricoperclórica para a preparação do extrato a partir do qual foram determinados esses nutrientes.

Realizou-se também a determinação da concentração média de fósforo e de zinco na parte aérea das plantas. Essa concentração foi obtida pela 
multiplicação do valor da massa seca de cada parte da planta (FE, LR, LM, CB) pela concentração do nutriente encontrada nestas partes. Somando-se esses valores, obteve-se o acúmulo do elemento que foi dividido pela massa seca total da parte aérea, encontrando-se essa concentração média.

\subsection{Determinação da clorofila}

Para a determinação da clorofila nas folhas do capim-Tanzânia, coletaram-se cinco discos foliares em cada vaso com vasador de rolhas de 1 $\mathrm{cm}^{2}$, aos 52 dias do crescimento das plantas. Colocaram-se as amostras em saquinhos de alumínio que foram congeladas à temperatura de $-80^{\circ} \mathrm{C}$.

No laboratório, deixaram-se as amostras em nitrogênio líquido enquanto ficaram fora do congelador. Para a maceração das amostras, colocaram-se em um recipiente areia lavada e a amostra congelada macerando-se até formar um pó fino. Adicionaram-se $10 \mathrm{ml}$ de acetona $80 \%$ tamponada em carbonato de potássio ( $\mathrm{pH}=9$ a 12). Macerou-se novamente e transferiu-se o líquido com a pipeta para tubos de ensaio. Centrifugou-se por 2 minutos e mediu-se a absorbância no espectrofotômetro. A leitura foi realizada nos comprimentos de onda de 663,6 e 646,6 e a quantidade de clorofila determinada conforme trabalho de Porra et al. (1989).

\subsection{Análises estatísticas}

Todos os resultados do experimento receberam o recomendado tratamento estatístico, com análise em superfície de resposta por meio do procedimento RSREG do "Statistical Analysis System" (SAS-Windows, 1989). Quando a interação entre doses de fósforo e zinco não foi significativa, realizouse a análise de regressão para fósforo e para zinco, testando-se modelos de primeiro e segundo graus, pelo procedimento GLM. O nível de significância adotado foi de $5 \%$. 


\section{RESULTADOS E DISCUSSÃO}

\subsection{Número de perfilhos}

A interação entre doses de fósforo e de zinco não foi significativa para o número de perfilhos do capim-Tanzânia, tanto no primeiro como no segundo crescimentos.

O número de perfilhos nos dois crescimentos da gramínea variou significativamente em função das doses de fósforo, ajustando-se ao modelo quadrático de regressão (Figuras 2 e 3). O máximo número de perfilhos foi encontrado na dose de fósforo de $1,37 \mathrm{mmol} \mathrm{L}^{-1}$ no primeiro crescimento e de $1,34 \mathrm{mmol} \mathrm{L}^{-1}$ no segundo crescimento.

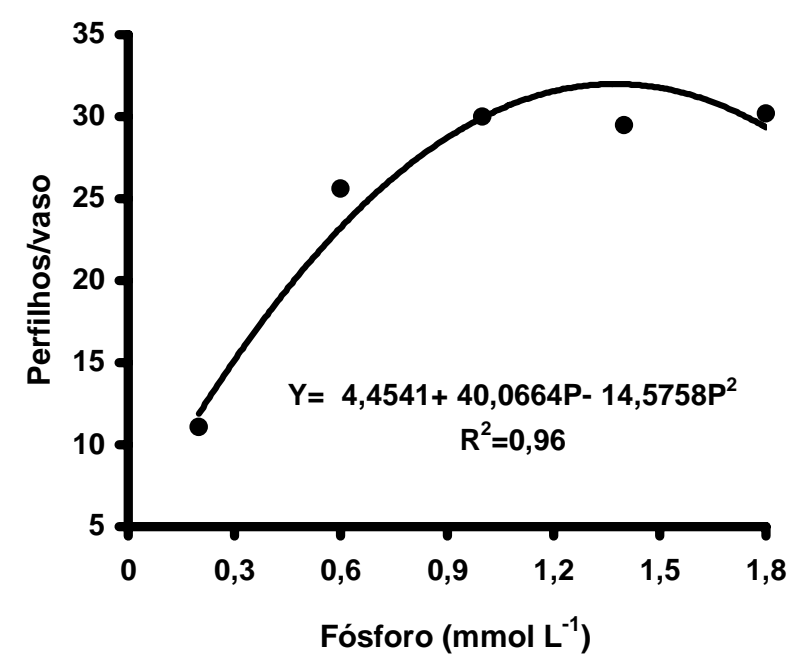

Figura 2 - Número total de perfilhos no primeiro crescimento do capimTanzânia, em função das doses de fósforo 
A alta demanda de fósforo no período de implantação do capim concorda com Werner (1986), que relatou ter o fósforo grande importância para as forrageiras nos períodos iniciais do desenvolvimento, particularmente para o perfilhamento. Esse papel do fósforo no perfilhamento do capim proporciona maior fechamento da pastagem, evitando áreas de solo descoberto que pode resultar em erosão ou invasão por plantas daninhas.

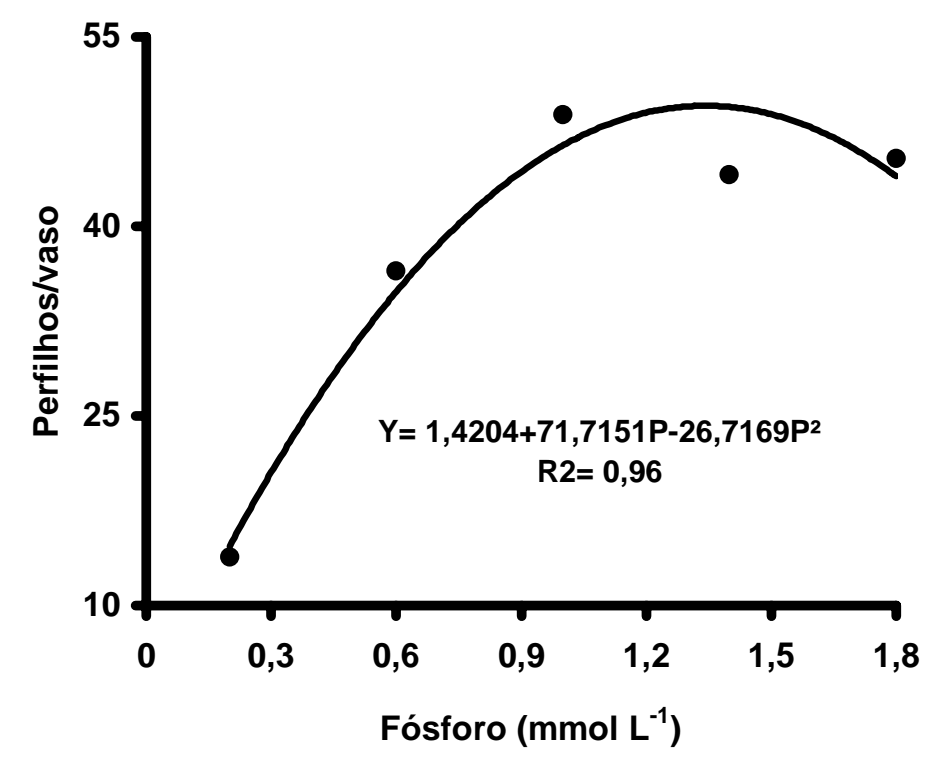

Figura 3 - Número total de perfilhos no segundo crescimento do capimTanzânia, em função das doses de fósforo

Oliveira et al. (2004) verificaram, para o capim-de-raiz (Chloris orthonoton), aumento no número de perfilhos quando compararam a não aplicação de fósforo com a dose de $100 \mathrm{~kg} \mathrm{ha}^{-1}$, não ocorrendo diferença significativa no número de perfilhos entre as doses de 100 e $200 \mathrm{~kg} \mathrm{ha}^{-1}$.

Brito Filho et al. (1999), trabalhando com doses de fósforo de 0, 50, 100, 150 e $200 \mathrm{~kg} \mathrm{ha}^{-1}$ ano $^{-1}$ para o capim-Marandu, encontraram aumento linear no número total de perfilhos, no número de perfilhos vivos e no número de perfilhos decapitados, mediante as doses de fósforo. 
Almeida (1998) aplicou fósforo nas doses de 3,1, 15,5 e $31 \mathrm{mg} \mathrm{L}^{-1} \mathrm{em}$ solução nutritiva e verificou que o aumento das doses de fósforo estimulou o perfilhamento de dois capins do gênero Brachiaria na fase de estabelecimento e durante o crescimento. O perfilhamento da Brachiaria decumbens ajustou-se ao modelo linear de regressão e o da Brachiaria brizantha ao modelo quadrático, em função das doses de fósforo.

Hoffmann et al. (1995) constataram, em experimento realizado num Latossolo adicionando doses de fósforo de 0 a $450 \mathrm{mg} \mathrm{kg}^{-1}$ de solo, tanto para o capim-Colonião quanto para o capim-Braquiária, que o número de perfilhos variou em função do suprimento de fósforo no solo e que o máximo número de perfilhos foi encontrado para o capim-Colonião com a dose de $297,62 \mathrm{mg} \mathrm{kg}^{-1} \mathrm{e}$ para o capim-Braquiária na dose de $300 \mathrm{mg} \mathrm{kg}^{-1}$.

\subsection{Número de folhas}

$\mathrm{Na}$ análise de variância para o número total de folhas verdes expandidas do capim-Tanzânia não se verificou significância para a interação entre as doses de fósforo e de zinco fornecidas na solução, nos dois períodos de crescimentos. No entanto, foi verificada significância para as doses de fósforo no primeiro e no segundo crescimentos, ajustando-se a modelo quadrático de regressão. Os máximos números de folhas ocorreram nas doses de fósforo de $1,37 \mathrm{mmol} \mathrm{L}^{-1}$ para o primeiro crescimento e 1,31 $\mathrm{mmol} \mathrm{L}^{-1} \mathrm{no}$ segundo (Figuras 4 e 5).

Verifica-se que as doses de fósforo aplicadas para a obtenção do máximo número de folhas são muito próximas das doses que proporcionaram os maiores números de perfilhos na forrageira. Estes parâmetros se correlacionam porque quanto mais perfilhos, maior é o número de folhas das plantas. 
Melo (2005) verificou aumento no número de folhas do capimMarandu com o fornecimento de fósforo até a dose de $130 \mathrm{mg} \mathrm{dm}^{-3}$, em presença de alta dose de silício ao Latossolo Vermelho-Amarelo distrófico. Conforme diminuiu a dose de silício no solo, fez-se necessário aumentar a dose de fósforo até $250 \mathrm{mg} \mathrm{dm}^{-3}$, para se obter o número máximo de folhas desse capim.

Outros trabalhos buscaram verificar a variação do número de folhas de forrageiras em função dos nutrientes aplicados ao solo e na solução. Garcez-Neto et al. (2002) aplicaram nitrogênio nas doses de 0, 50, 100 e 200 $\mathrm{mg} \mathrm{dm}^{-3}$ num Latossolo Vermelho-Amarelo de textura franco-argilosa e constataram aumento linear no número de folhas verdes do capim-Mombaça (Panicum maximum) em função das doses aplicadas. Batista (2002), adicionou doses de nitrogênio (14 a $462 \mathrm{mg} \mathrm{L}^{-1}$ ) e enxofre (3,2 a $80 \mathrm{mg} \mathrm{L}^{-1}$ ) na solução nutritiva para o capim-Marandu e encontrou aumento no número de folhas quando aplicou os nutrientes em quantidades balanceadas.

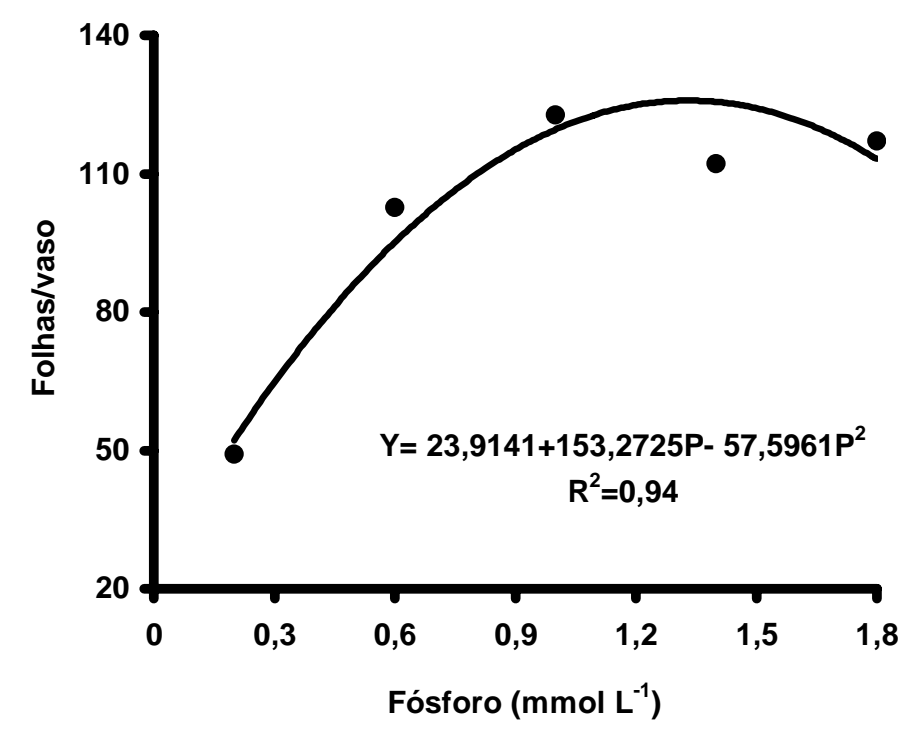

Figura 4 - Número total de folhas no primeiro crescimento do capim-Tanzânia, em função das doses de fósforo 


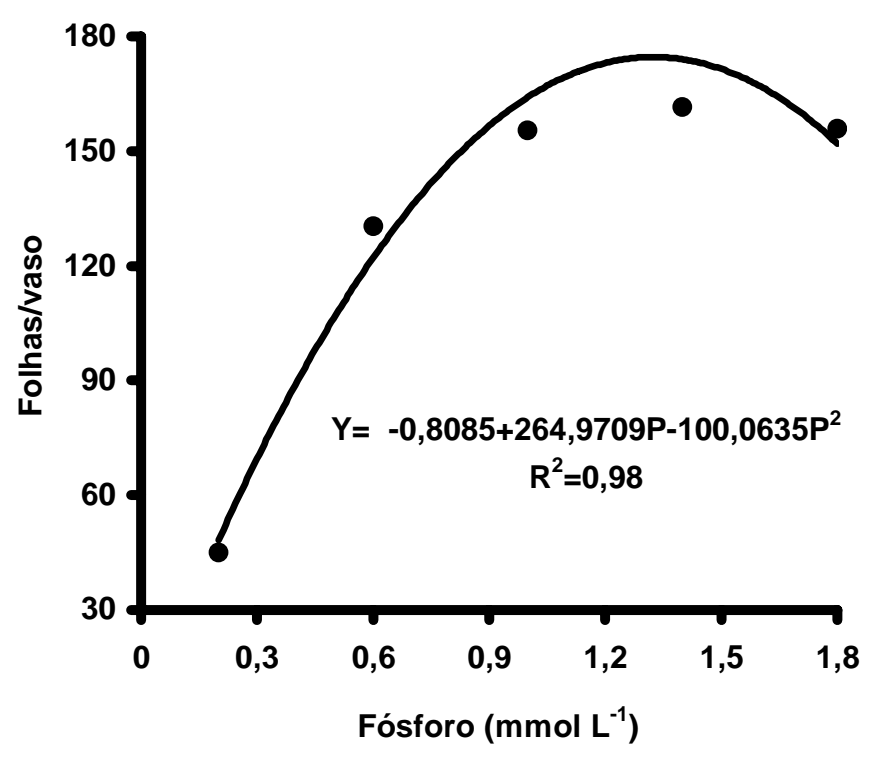

Figura 5 - Número total de folhas no segundo crescimento do capim-Tanzânia, em função das doses de fósforo

\section{3 Área foliar}

A interação entre as doses de fósforo e de zinco não foi significativa para a área foliar no primeiro corte das plantas, mas ocorreram significâncias em função das doses de fósforo e de zinco separadamente. Em ambos os casos foram obtidos ajustes a modelo quadrático de regressão (Figuras 6 e 7).

No primeiro corte, o máximo valor de área foliar foi encontrado na dose de fósforo $1,38 \mathrm{mmol} \mathrm{L}^{-1}$ e na dose de zinco $0,41 \mu \mathrm{mol} \mathrm{L}^{-1}$. Ressalta-se que a dose de fósforo para se obter a máxima área foliar é próximo daqueles para maior número de folhas e perfilhos.

O zinco contribuiu para o aumento da área foliar (Figura 7) sendo que este nutriente aumenta a concentração de clorofila e a eficiência da fotossíntese, como observado por Ohki (1976) em plantas de algodão. 


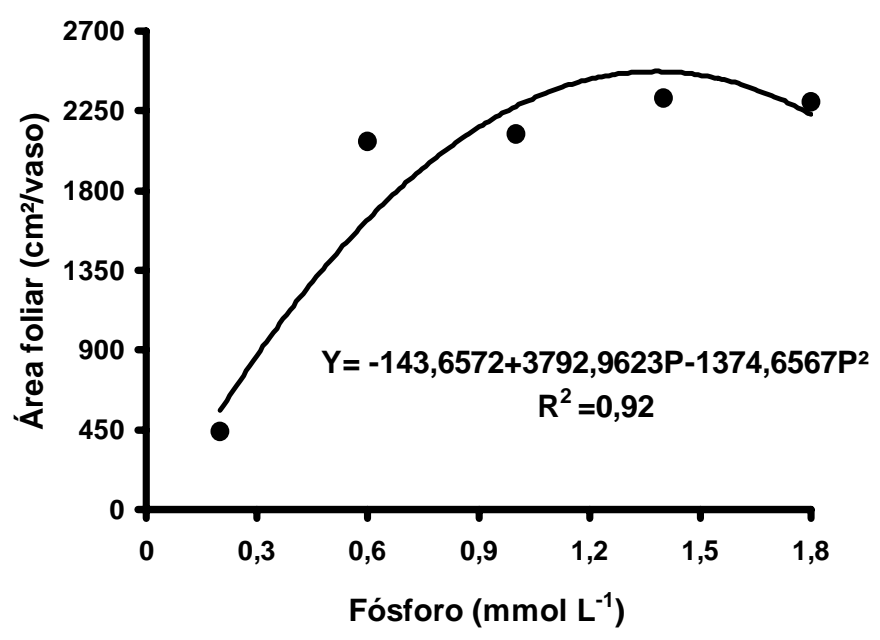

Figura 6 - Área foliar na ocasião do primeiro corte do capim-Tanzânia, em função das doses de fósforo

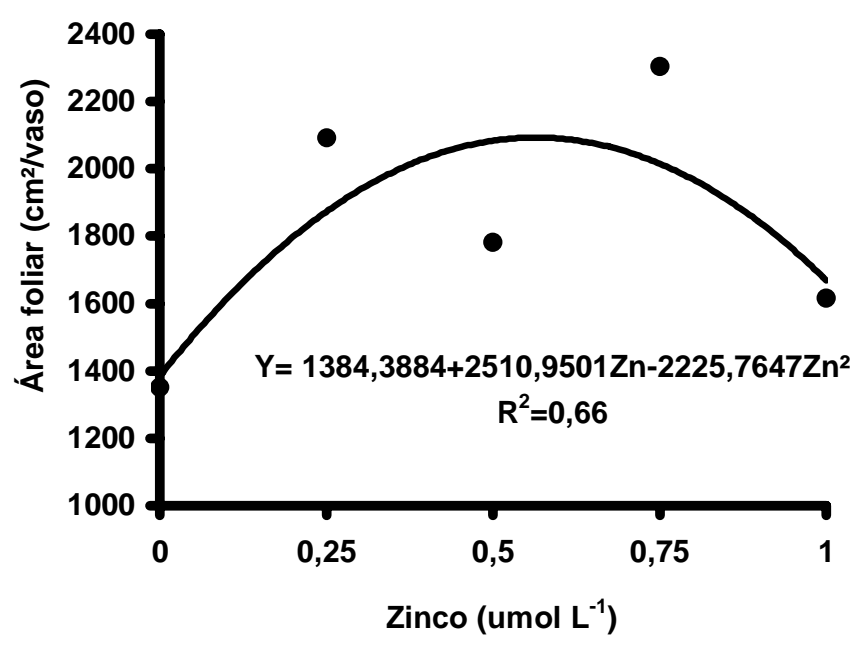

Figura 7 - Área foliar no primeiro corte do capim-Tanzânia, em função de doses de zinco

Na área foliar avaliada à época do segundo corte, a interação entre as doses de fósforo e de zinco foi significativa ajustando-se a modelo polinomial de regressão, conforme o estudo de superfície de resposta (Figura 8). O ponto para o valor máximo de área foliar foi encontrado na dose $1,31 \mathrm{mmol} \mathrm{L}^{-1}$ de fósforo, e na dose $0,92 \mu \mathrm{mol} \mathrm{L}{ }^{-1}$ de zinco. De acordo com a Figura 8 observa-se 
que existe uma área de máximo valor de área foliar ocorrendo entre as doses de fósforo de 1 a $1,8 \mathrm{mmol} \mathrm{L}^{-1}$ combinadas com as doses de zinco de 0,125 a $1,00 \mu \mathrm{mol} \mathrm{L}^{-1}$.

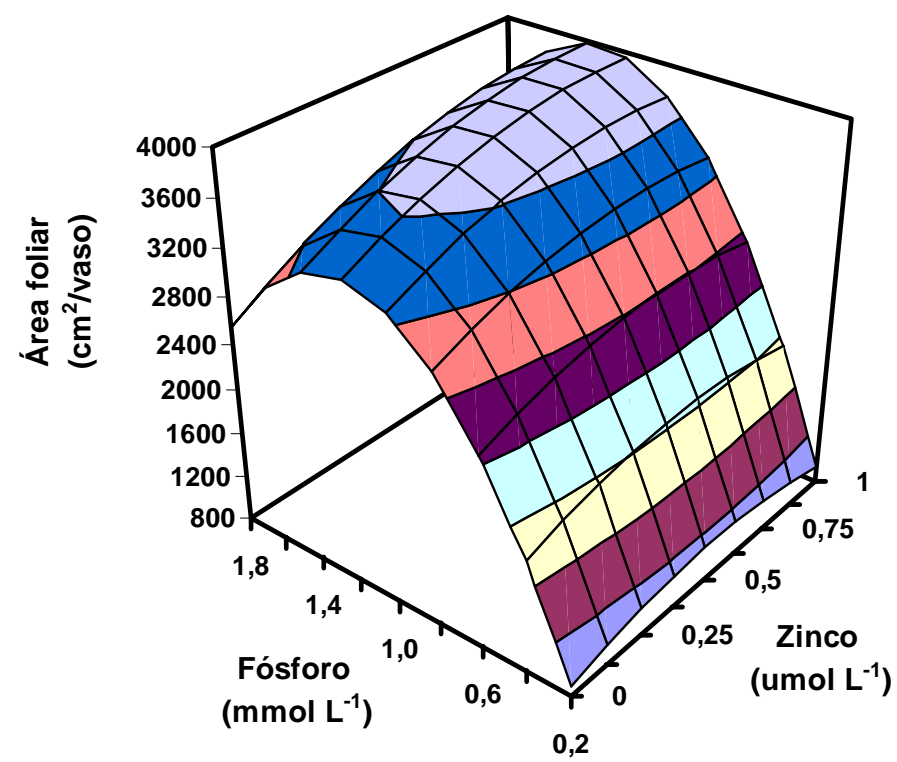

\begin{tabular}{|l|}
$\square 3600-4000$ \\
$\square 3200-3600$ \\
$\square 2800-3200$ \\
$\square 2400-2800$ \\
$\square 2000-2400$ \\
$\square 1600-2000$ \\
$\square 1200-1600$ \\
$\square 800-1200$ \\
\hline
\end{tabular}

$$
\begin{gathered}
Y=-188,7662+5869,7369 P-2418,3051 P^{2}+714,6475 Z n-758,8012 Z n^{2}+517,9316 P Z n \\
R^{2}=0,89
\end{gathered}
$$

Figura 8 - Área foliar do capim-Tanzânia, na época do segundo corte, em função das combinações entre doses de fósforo e de zinco

Melo (2005) verificou, para o primeiro crescimento do capimMarandu, aumento na área foliar até a dose máxima de fósforo aplicada ao solo que foi de $330 \mathrm{mg} \mathrm{dm}^{-3}$. Para o segundo crescimento, observou aumento de até duas vezes neste parâmetro quando se comparou a dose mínima de 10 $\mathrm{mg} \mathrm{dm}$ com a dose de $130 \mathrm{mg} \mathrm{dm}^{-3}$, que apresentou o ponto máximo para área foliar.

Moreira et al. (2001), aplicando doses de fósforo $(0,01,1,5$ e 6,0 mmol L $\left.{ }^{-1}\right)$ e de zinco $\left(0,0,1,5\right.$ e $\left.6,0 \mathrm{mmol} \mathrm{L}^{-1}\right)$ em plantas de alface, verificaram aumento da área foliar ao se aplicar zinco junto às doses de fósforo de 1,5 e 6,0 mmol L ${ }^{-1}$ sendo que para a dose de fósforo de $0,01 \mathrm{mmol} \mathrm{L}^{-1}$, não foi necessária a aplicação de zinco. 


\subsection{Massa seca da parte aérea}

A interação entre as doses de fósforo e de zinco foi significativa para a produção de massa seca da parte aérea por ocasião do primeiro corte (Figura 9), ajustando-se a modelo polinomial de regressão. O ponto para o máximo valor de massa seca da parte aérea foi encontrado na dose $1,47 \mathrm{mmol} \mathrm{L}^{-1}$ para fósforo e 0,75 $\mu \mathrm{mol} \mathrm{L^{-1 }}$ para zinco. Porém, observa-se na Figura 9 que existe uma área de produção máxima, variando entre as doses de fósforo de 1,0 a 1,8 mmol $\mathrm{L}^{-1}$ combinadas com as doses de zinco de 0,125 a $1,0 \mu \mathrm{mol} \mathrm{L} \mathrm{L}^{-1}$.

A dose de fósforo para máxima produção corresponde às encontradas para obtenção de maiores números de folhas e de perfilhos e máxima área foliar. Isto se mostra muito coerente, pois a produção das forrageiras é dependente direta destas variáveis.

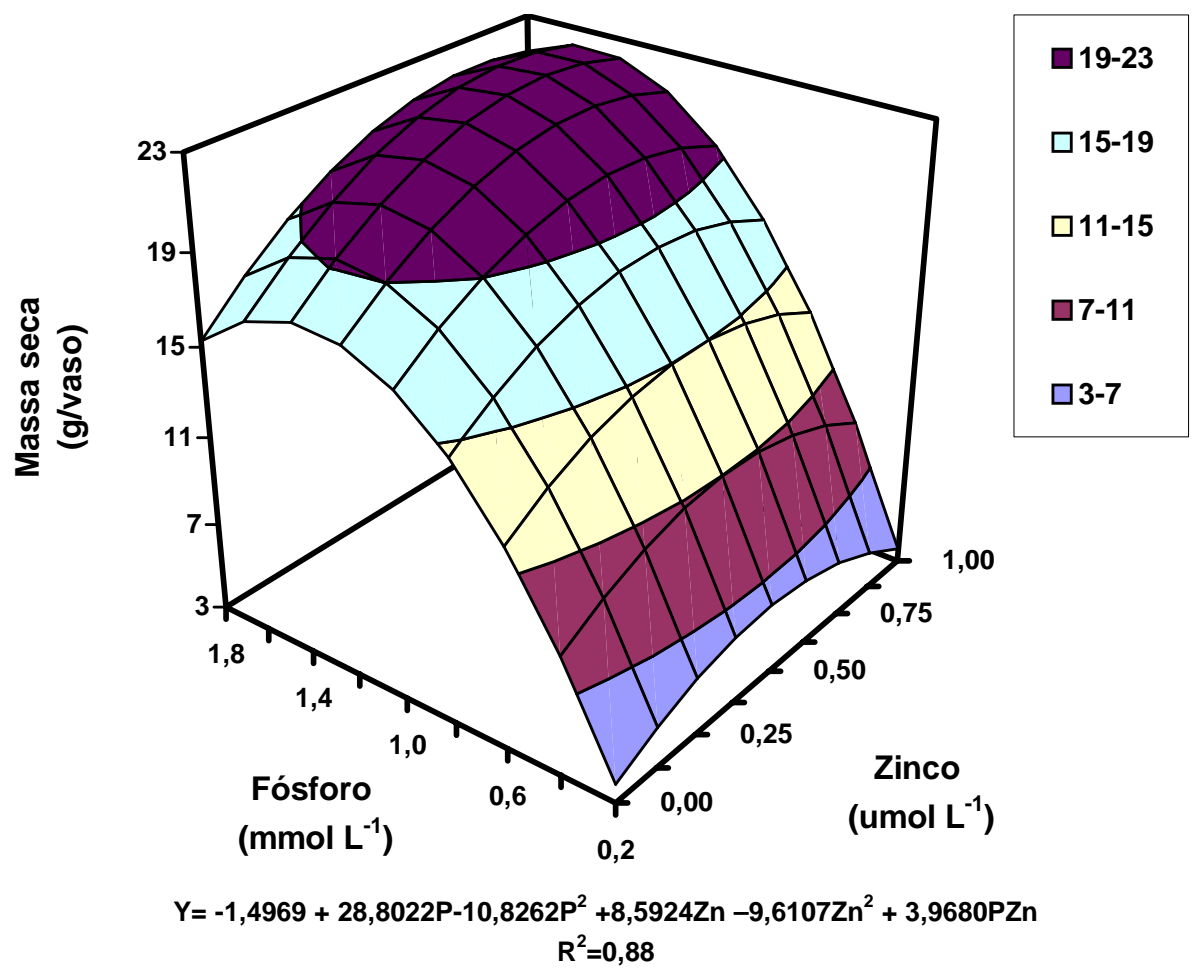

Figura 9 - Produção de massa seca na parte aérea, no primeiro corte, do capimTanzânia, em função das combinações entre doses de fósforo e de zinco 
Souza et al. (1998) verificaram, em experimento de campo, mediante a adição de zinco junto ao fósforo num Latossolo Vermelho-Escuro, que ocorreu aumento na produção de grãos de milho e que a aplicação do zinco foi necessária para aumentar a produção quando se almeja que esta tenha valores acima de $6000 \mathrm{~kg} \mathrm{ha}^{-1}$ (produtividade muito maior que a média nacional). Galrão \& Mesquita Filho (1981) realizaram um experimento em casa-devegetação, num Latossolo Vermelho-Amarelo, com doses de zinco de 0,0, 1,25, 2,5, 5,0 e 10,0 $\mathrm{mg} \mathrm{dm}^{-3}$ e observaram que o zinco proporcionou aumento de massa seca do milho quando comparado à testemunha.

Quanto ao segundo corte, a interação entre doses de fósforo e zinco não foi significativa, mas ocorreu significância para as doses de fósforo, cujos resultados se ajustaram ao modelo quadrático de regressão (Figura 10). A máxima produção de massa seca foi encontrada na dose de fósforo de 1,31 $m m o l ~ L^{-1}$. Esse valor, novamente corresponde às doses observadas para 0 máximo número de perfilhos, número de folhas e máxima área foliar, em função da participação destas variáveis na produção do capim-Tanzânia.

No segundo corte, a produção de massa seca foi superior a do primeiro corte. Isto pode ser explicado porque na fase de estabelecimento a planta está estruturando a parte aérea e formando raízes e no segundo crescimento, a planta já estabelecida, pode utilizar os compostos e a energia para o crescimento.

Melo (2005) verificou, num experimento em casa-de-vegetação e aplicando doses de fósforo que variaram de 10 a $330 \mathrm{mg} \mathrm{dm}^{-3}$, aumento na produção de massa seca do capim-Marandu com a aplicação do nutriente no Latossolo Vermelho-Amarelo distrófico, no primeiro e no segundo crescimento das plantas.

Magalhães et al. (2004) verificaram aumento linear na produção de massa seca em função do incremento de fósforo para a Brachiaria decumbens, num experimento de campo, num Podzólico Vermelho Amarelo distrófico. Gheri 
et al. (2000) constataram que o incremento de fósforo (0 a $140 \mathrm{mg} \mathrm{dm}^{-3}$ ) causa aumento de massa seca no capim-Tanzânia, nos três solos utilizados no experimento, com o maior acréscimo ocorrendo da não aplicação para a dose de $35 \mathrm{mg} \mathrm{dm}^{-3}$.

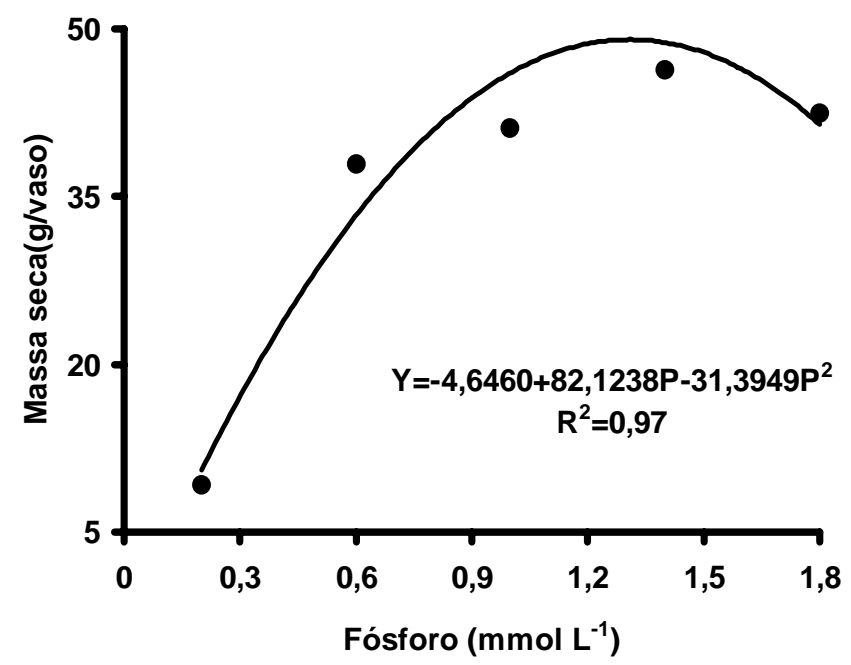

Figura 10 - Produção de massa seca da parte aérea no segundo corte do capimTanzânia, em função das doses de fósforo

Rossi (1999), estudando doses de fósforo em solução nutritiva para o capim-Braquiária e capim-Colonião, encontrou aumento linear na produção de massa seca das forrageiras com o incremento nas doses de fósforo (3,1; 15,5 e $31,0 \mathrm{mg} \mathrm{L}^{-1}$ ). Verificou diferenças entre as espécies, sendo que o capimColonião mostrou-se mais exigente em fósforo nas fases iniciais de seu desenvolvimento do que o capim-Braquiária.

A exemplo do constatado neste trabalho, Almeida (1998) aplicou as doses de fósforo de 3,1, 15,5 e $31 \mathrm{mg} \mathrm{L}^{-1}$ e constatou variação quadrática na produção de massa seca da parte aérea da Brachiaria brizantha, em função das doses de fósforo na solução nutritiva.

Corrêa (1991) aplicou doses de fósforo de 0 a $560 \mathrm{mg} \mathrm{kg}^{-1}$ em três espécies de gramíneas forrageiras e encontrou aumento na produção da massa seca até a dose de $\mathrm{P}_{2} \mathrm{O}_{5}$ de $140 \mathrm{~kg} \mathrm{ha}^{-1}$. Corrêa et al. (1997) verificaram que a 
produção de massa seca da parte aérea do capim-Tanzânia aumentou com o fornecimento de fósforo ao Latossolo Vermelho-Amarelo Álico.

\subsection{Valor SPAD}

$\mathrm{Na}$ análise de variância para o valor SPAD não se verificou significância para a interação entre as doses de fósforo e as doses de zinco fornecidas na solução, quer no primeiro ou no segundo crescimento do capimTanzânia. A significância foi verificada para essa variável no primeiro crescimento em relação às doses de fósforo (Figura 11), sendo o máximo valor encontrado na dose de $1,40 \mathrm{mmol} \mathrm{L}^{-1}$.

Almeida (1998) verificou, para o primeiro crescimento da forrageira, que o valor SPAD ajustou-se ao modelo quadrático de regressão em função do fósforo aplicado na solução. Assim, fica evidente a necessidade de se relacionar a medida do clorofilômetro com a disponibilidade de outros nutrientes às plantas que não só o nitrogênio, como constantemente tem se observado em trabalhos. Manarin (2000) variou as doses de nitrogênio em solução nutritiva para o capim-Mombaça e encontrou alteração no valor SPAD, obtendo o máximo valor na dose de $419,3 \mathrm{mg} \mathrm{L}^{-1}$ no primeiro crescimento, enquanto para o segundo crescimento o aumento foi linear em função do nitrogênio fornecido.

Santos (1997) encontrou correlação entre os resultados de leitura SPAD e os da concentração de enxofre na planta, observando que ao aumentar o enxofre na solução houve aumento na unidade SPAD, até o máximo valor que foi de 43,1 encontrado com a dose de $39 \mathrm{mg} \mathrm{L}^{-1}$ de enxofre aplicado na solução. 


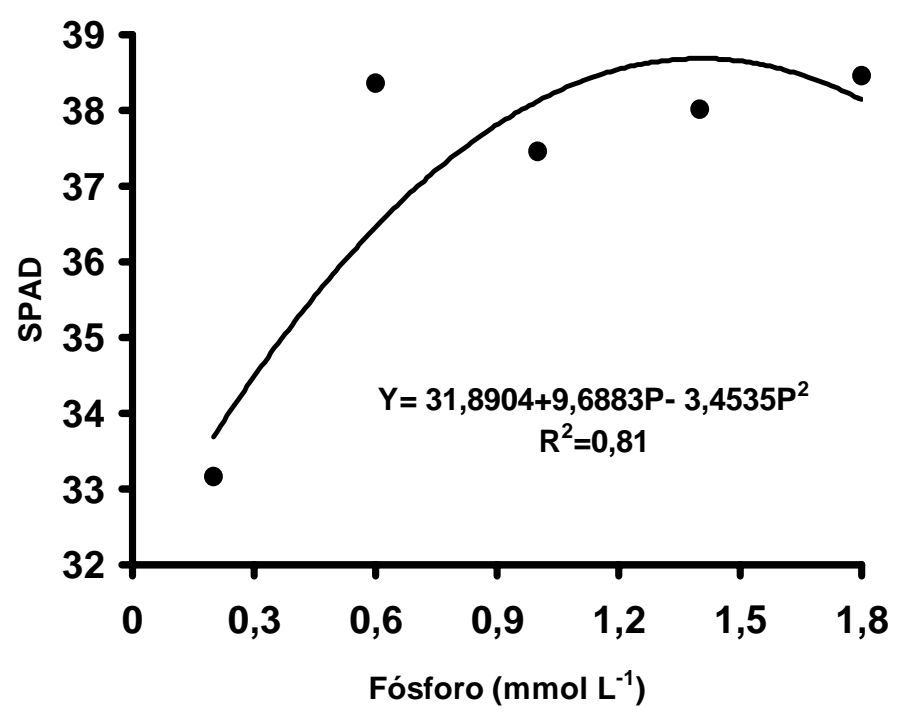

Figura 11 - Valor SPAD no primeiro crescimento do capim-Tanzânia, em função das doses de fósforo

\subsection{Clorofila na parte aérea}

A interação entre doses de fósforo e zinco não foi significativa para a concentração de clorofila nas folhas do capim-Tanzânia. Não foram verificadas significâncias para a concentração de clorofila na plantas em função das doses de fósforo e zinco fornecidas na solução. O valor médio de clorofila "a" encontrado nas plantas foi de 10,83; de clorofila "b" de 17,54 e de clorofila " $a+b$ " foi de $20,06 \mu \mathrm{gL}^{-1}$.

Ohki (1976) determinou a quantidade de clorofila em folhas de algodão que apresentavam deficiência de zinco e verificou diminuição da concentração de clorofila nas plantas quando comparadas com aquelas bem nutridas o que difere do presente trabalho. 
4.7 Massa seca, comprimento, comprimento específico e superfície de raízes

\subsubsection{Massa seca das raízes}

A interação entre as doses de fósforo e zinco foi significativa para a produção de massa seca das raizes (Figura 12), ajustando-se a modelo polinomial de regressão.Observa-se que até a dose de fósforo de 1,0 $\mathrm{mmol} \mathrm{L}^{-1}$ houve aumento de massa seca de raízes, independente da dose de zinco aplicada ao substrato. Porém, quando se aumenta a dose de zinco, necessitase de doses menores de fósforo para atingir a máxima produção de massa seca de raízes.

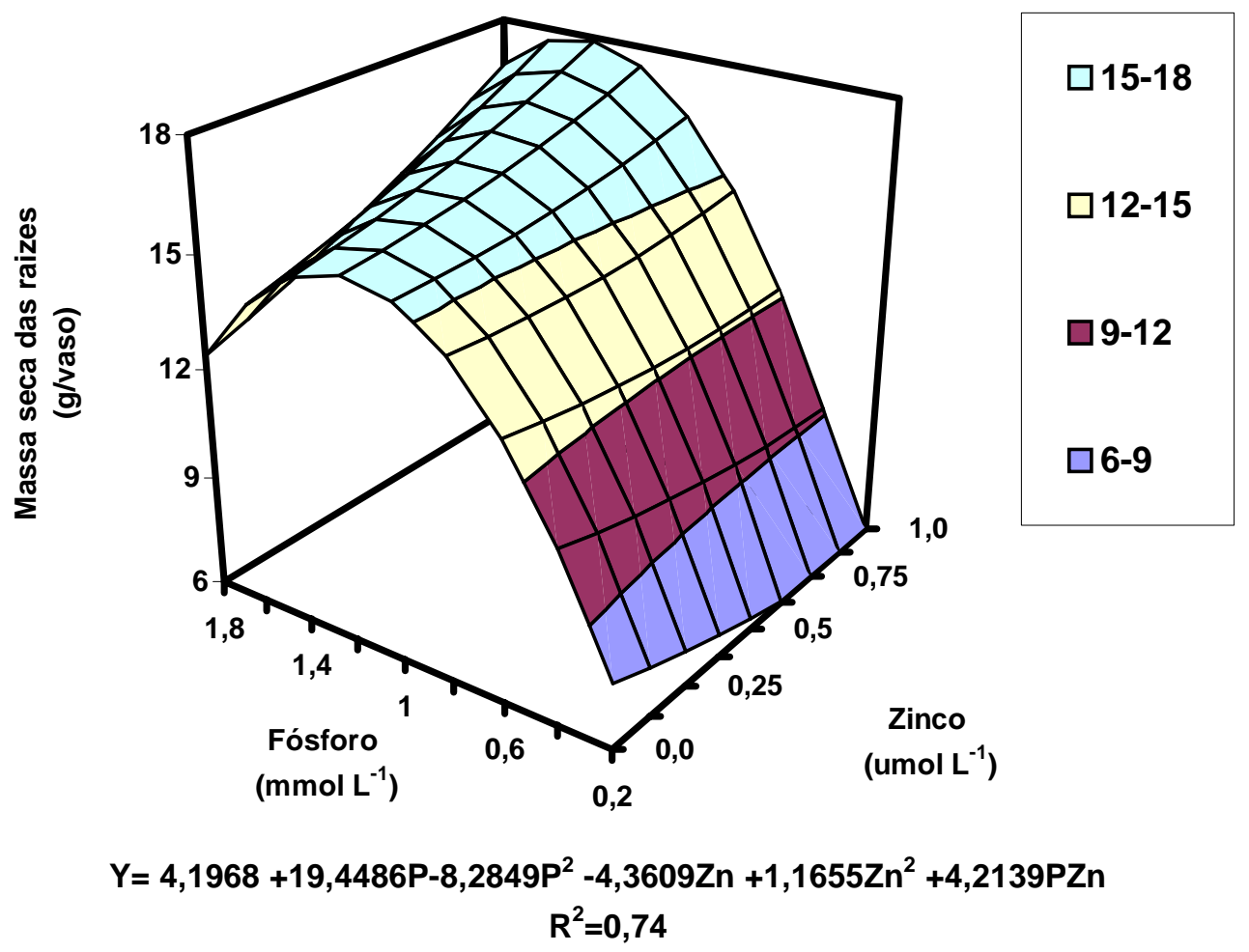

Figura 12 - Produção de massa seca de raízes do capim-Tanzânia, em função das combinações entre doses de fósforo e de zinco

Rossi (1999), ao estudar a resposta do capim-Colonião às doses de fósforo de 3,1, 15,5 e 31,0 $\mathrm{mg} \mathrm{L}^{-1}$ em solução nutritiva e em dez épocas, verificou aumento linear na produção de massa seca de raízes em função das 
doses de fósforo, em todos os períodos estudados. Almeida (1998) também encontrou efeito do fósforo na massa seca de raízes do capim-Braquiária quando empregou doses de fósforo de $3,1,15,5$ e $31,0 \mathrm{mg} \mathrm{L}^{-1}$ na solução nutritiva, verificando aumento linear na produção de massa seca de raízes com o incremento do nutriente.

Silva (1996) trabalhou com doses de fósforo de 3,1, 15,5 e $31 \mathrm{mg} \mathrm{L}^{-1}$ em solução nutritiva e concluiu que o aumento das doses de fósforo proporcionou aumento na produção de massa seca das raízes de Brachiaria brizantha, Brachiaria decumbens e Panicum maximum cv. IZ-1.

Ohki (1976) colocou plantas de algodão para crescer em solução nutritiva com doses de zinco que variaram entre 10 e $2000 \mu \mathrm{g} \mathrm{L}^{-1}$. Observou aumento na massa seca de raizes da dose 10 para a dose de $2000 \mu \mathrm{g} \mathrm{L}^{-1}$.

Fageria (2000) trabalhou com doses de zinco de 0 a $120 \mathrm{mg} \mathrm{kg}^{-1}$ de solo e verificou aumento na massa seca de raizes das plantas de arroz e trigo em função do suprimento de fósforo no Latossolo Vermelho-Escuro.

\subsubsection{Comprimento das raízes}

A interação entre as doses de fósforo e de zinco não foi significativa para o comprimento das raízes, sendo significativa apenas para as doses de fósforo aplicadas ao substrato e ajustando-se ao modelo quadrático de regressão (Figura 13). A dose de fósforo de $1,39 \mathrm{mmol} \mathrm{L}^{-1}$ foi a que promoveu maior comprimento radicular.

Melo (2005) verificou que o comprimento radicular do capim-Marandu aumentou até a dose de fósforo de $330 \mathrm{mg} \mathrm{dm}^{-3}$, aplicada ao Latossolo Vermelho-Amarelo distrófico. Observou valores de comprimento próximos a $85 \mathrm{~m}$ por vaso, sendo inferior ao encontrado no presente trabalho com capimTanzânia onde os valores máximos aproximam-se de $750 \mathrm{~m}$ por vaso. Batista (2002) aplicou nitrogênio na solução nutritiva para o capim-Marandu, variando as doses de 14 a $462 \mathrm{mg} \mathrm{L}^{-1}$ e verificou resposta quadrática no comprimento de 
raízes, chegando ao valor máximo de $827 \mathrm{~m}$ em função das doses de nitrogênio.

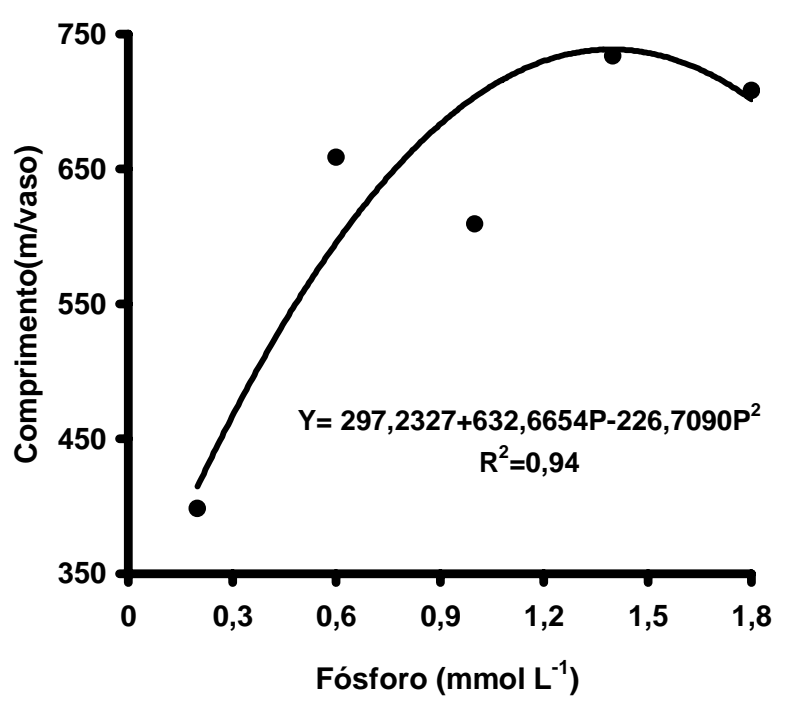

Figura 13 - Comprimento de raízes do capim-Tanzânia, em função das doses de fósforo

\subsubsection{Comprimento específico de raízes}

A interação entre doses de fósforo e de zinco não foi significativa para o comprimento específico de raízes, sendo significativa apenas em função das doses de fósforo ajustando-se ao modelo quadrático de regressão.

O comprimento específico de raízes foi mais alto na dose mais baixa de fósforo, mostrando que nesta dose o capim-Tanzânia tinha mais raízes finas e longas. Esses resultados concordam com Kanno et al. (2001), que relataram terem as doses de fósforo promovido decréscimo no comprimento específico de raízes. 


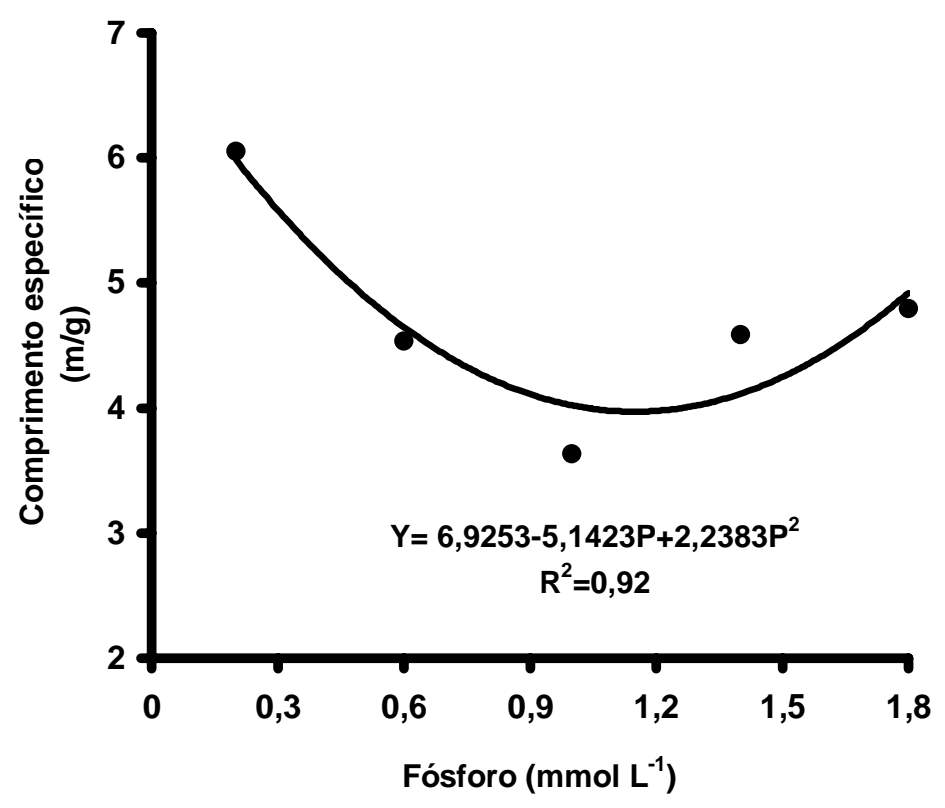

Figura 14 - Comprimento específico de raízes do capim-Tanzânia, em função das doses de fósforo

\subsubsection{Superfície das raízes}

$\mathrm{Na}$ análise de variância para a superfície total de raízes por vaso do capim-Tanzânia, a interação entre as doses de fósforo e zinco não foi significativa. Foi encontrada significância apenas para as doses de fósforo aplicadas ao substrato (Figura 15). A dose de fósforo que proporcionou a máxima superfície radicular foi a de $1,37 \mathrm{mmol} \mathrm{L}^{-1}$.

Melo (2005) encontrou respostas lineares em função das doses de fósforo para a superfície radicular do capim-Marandu, tendo obtido a máxima superfície radicular na dose de $330 \mathrm{mg} \mathrm{dm}^{-3}$ no Latossolo. Santos Junior (2001) estudou doses de nitrogênio 28 a $378 \mathrm{mg} \mathrm{L}^{-1}$ no capim-Marandu e constatou diferenças significativas entre as doses para a superfície radicular, observando que a dose de $312 \mathrm{mg} \mathrm{L}^{-1}$ proporcionou máximo valor de superfície radicular. 


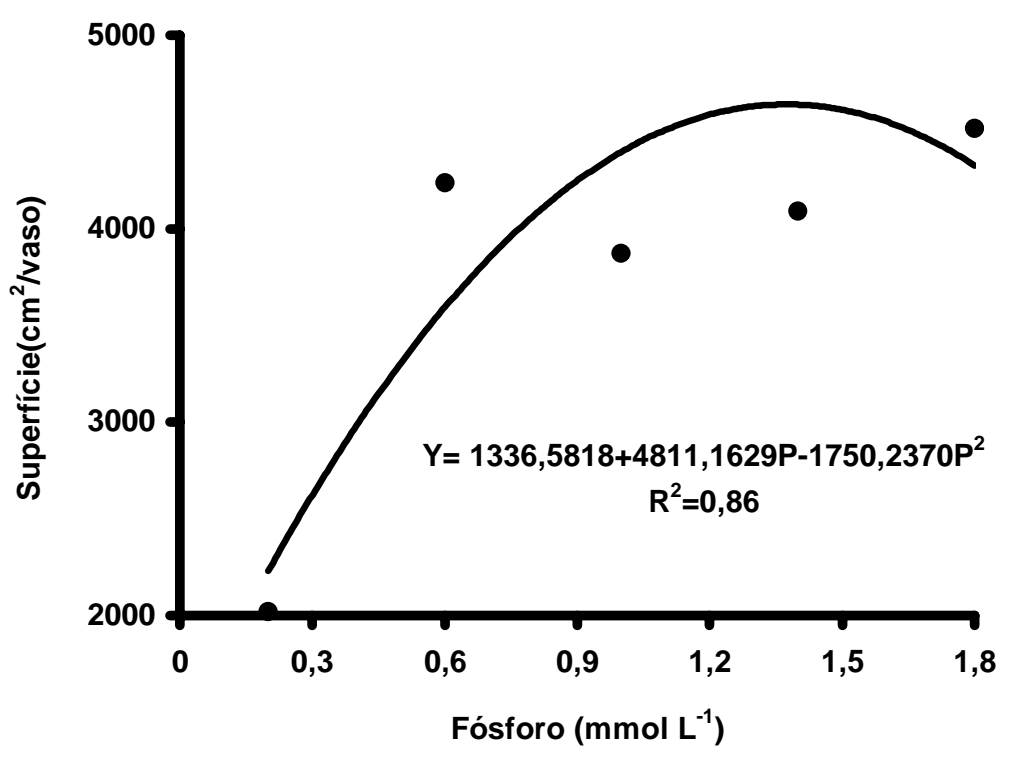

Figura 15 - Superfície de raízes do capim-Tanzânia, em função das doses de fósforo

\subsection{Concentração dos elementos no capim}

\subsubsection{Fósforo na parte aérea}

A interação entre as doses de fósforo e de zinco não foi significativa para a concentração de fósforo nas folhas emergentes (FE), nas lâminas de folhas recém-expandidas (LR) e nos colmos+bainhas (CB) do capim-Tanzânia, no material coletado no primeiro corte. Entretanto foi significativa para as lâminas de folhas maduras (LM), ajustando-se a modelo polinomial de regressão. Verificaram-se significâncias, em função das doses de fósforo, para a concentração de fósforo nas $\mathrm{FE}$, cujos resultados ajustaram-se ao modelo quadrático de regressão (Figura 16) e para as LR (Figura 17) e CB (Figura 19) que se ajustaram ao modelo de primeiro grau. A concentração máxima de fósforo nas folhas emergentes foi encontrada na dose de fósforo de $1,8 \mathrm{mg} \mathrm{L}^{-1} \mathrm{e}$ tem o valor de $2,64 \mathrm{mg} \mathrm{kg}^{-1}$. 


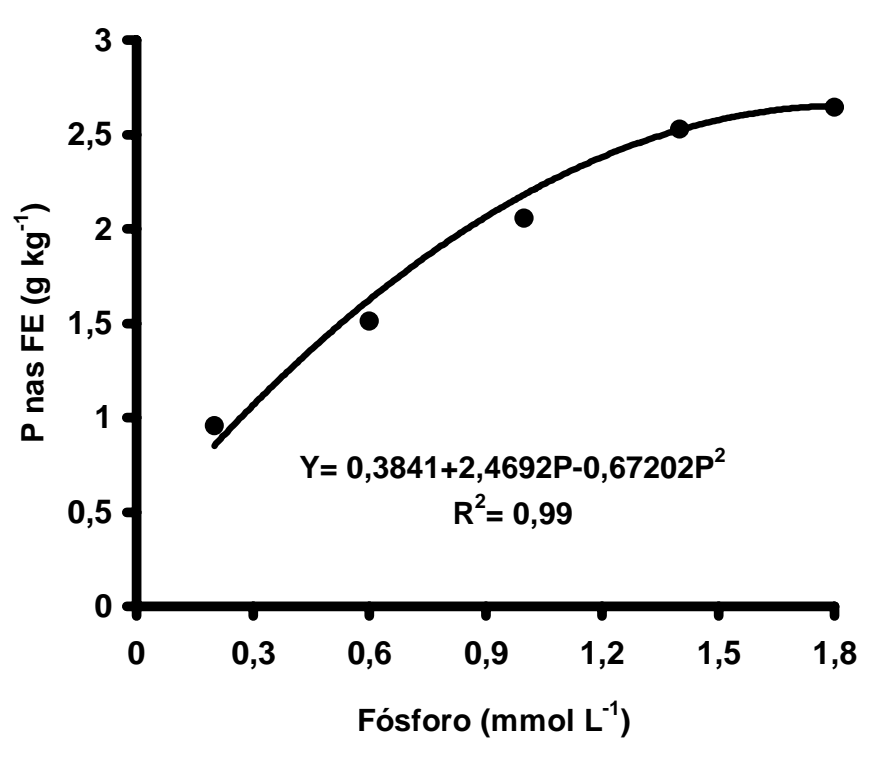

Figura 16 - Concentração de fósforo nas folhas emergentes (FE) coletadas no primeiro corte do capim-Tanzânia, em função das doses de fósforo

Melo (2005) trabalhou com doses de fósforo que variaram de $10 \mathrm{a}$ $330 \mathrm{mg} \mathrm{dm}^{-3}$ num Latossolo Vermelho-Amarelo e encontrou aumento na concentração de fósforo nas folhas emergentes (FE), em função das doses aplicadas, na ocasião do primeiro e do segundo corte do capim-Marandu. A concentração de fósforo na planta variou de 2,68 a $5,23 \mathrm{~g} \mathrm{~kg}^{-1}$, correspondendo às condições de baixa e alta dose de fósforo, respectivamente.

Nas LR (Figura 17) foi possível observar que no capim-Tanzânia a concentração de fósforo variou de 0,69 a $2,00 \mathrm{~g} \mathrm{~kg}^{-1}$, no primeiro crescimento. Deve-se destacar que as lâminas de folhas recém-expandidas são as que melhor representam o estado nutricional das plantas $\mathrm{e}$ as que são recomendadas para amostragem visando às análises de laboratório para fins de diagnose foliar (Monteiro, 1995).

Meirelles et al. (1988) adicionaram doses de fósforo de 0 a 400 $\mathrm{kg} \mathrm{ha}^{-1}$ num Latossolo Vermelho-Escuro e num Podzólico Vermelho-Amarelo e 
verificaram, nas três lâminas foliares recém-expandidas, valores críticos de 1,68 e $1,96 \mathrm{~g} \mathrm{~kg}^{-1}$ para as plantas crescidas em cada solo, respectivamente.

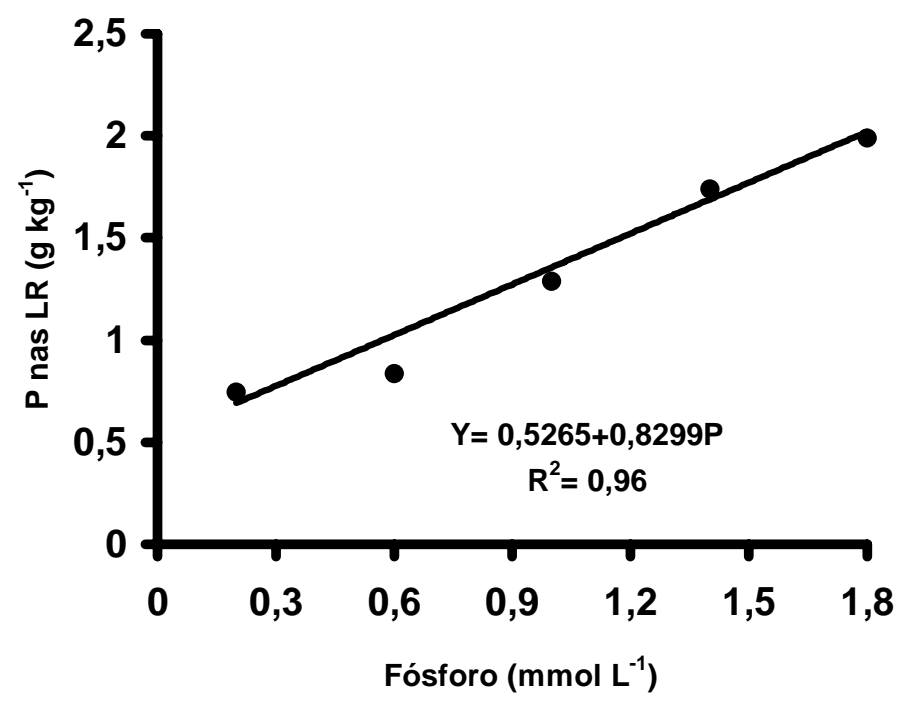

Figura 17 - Concentração de fósforo nas lâminas de folhas recém-expandidas (LR) do capim-Tanzânia, na ocasião do primeiro corte, em função das doses de fósforo

Rossi (1999) verificou que, para o capim-Colonião, as respostas foram lineares às doses de fósforo fornecidas na solução (de $3,1 \mathrm{a} 31 \mathrm{mg} \mathrm{L}^{-1}$ ) em todas as épocas de coleta. Para o capim-Braquiária encontrou aumento linear na concentração de fósforo, nas primeiras coletas e, conforme aumentou o tempo de cultivo da planta foi observada variação quadrática na concentração de fósforo.

Para as LM (Figura 17) existe uma região de máxima concentração de fósforo na dose de fósforo de 1,8 $\mathrm{mg} \mathrm{L}^{-1}$, com baixa dose de zinco. Porém, verifica-se que para doses medianas de fósforo na solução, o aumento na dose de zinco promove a maior concentração de fósforo na planta. 

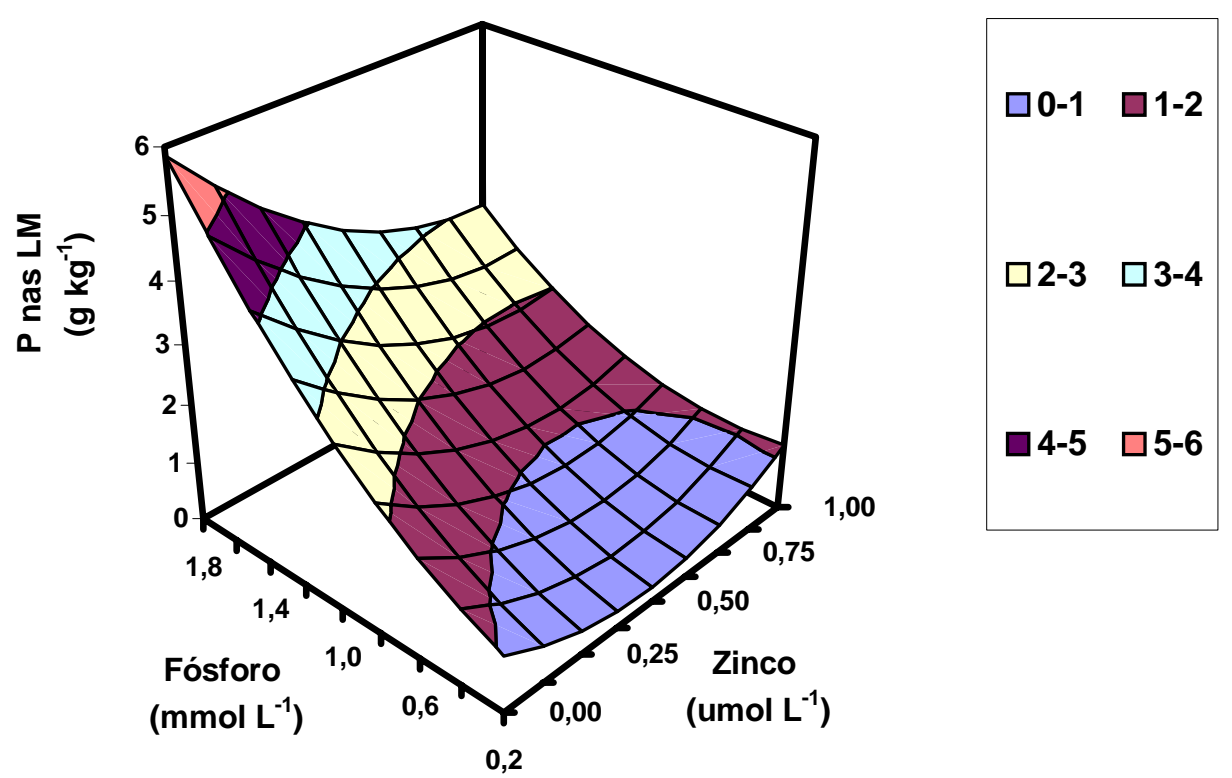

$Y=0,7005+0,993236 P+1,0429 P^{2}-2,528919 Z n+3,078393 Z n^{2}-1,923529 P Z n$ $R^{2}=0,71$

Figura 18 - Concentração de fósforo nas lâminas de folhas maduras (LM) do capim-Tanzânia, na ocasião do primeiro corte, em função combinações de das doses de fósforo e das de zinco

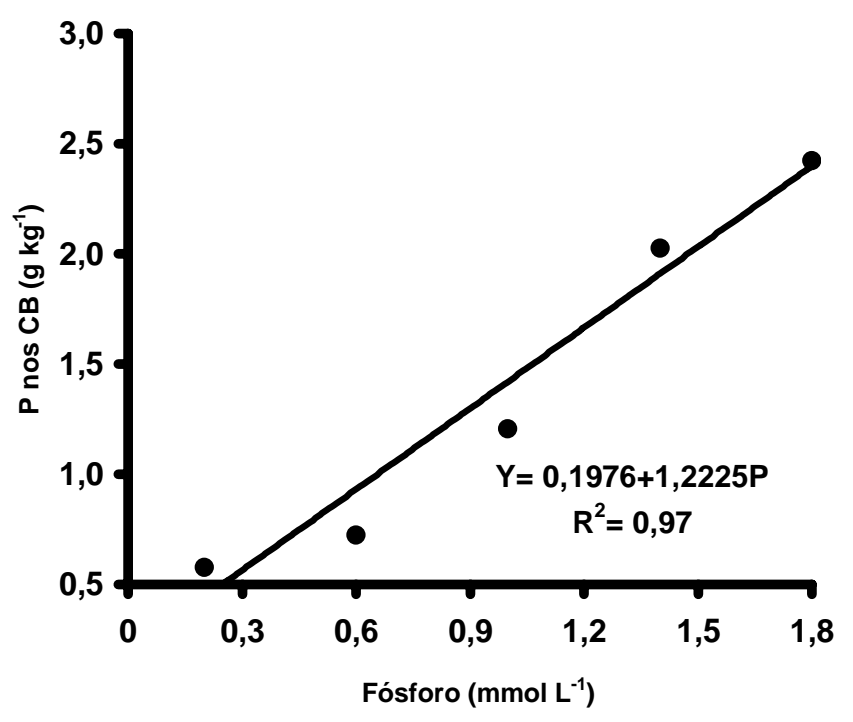

Figura 19 - Concentração de fósforo nos colmos mais bainhas (CB) do capimTanzânia, no primeiro corte, em função das doses de fósforo 
Quanto ao material coletado no segundo corte verificou-se que, para as LM, a interação entre as doses de fósforo e zinco foi significativa e os resultados ajustaram-se a modelo polinomial de regressão. Para as demais partes da planta, verificaram-se significâncias em função das doses de fósforo, sendo que as FE ajustaram-se ao modelo linear de regressão (Figura 20) e as LR (Figura 21) e CB (Figura 23) ao modelo quadrático de regressão.

Hoffmann et al. (1995) adicionaram doses de fósforo que variaram de 0 a $450 \mathrm{mg} \mathrm{kg}^{-1}$ ao Latossolo Vermelho-Escuro, textura média. Determinaram, para o segundo corte, uma concentração nas lâminas de folhas recémexpandidas (LR) de $2,4 \mathrm{~g} \mathrm{~kg}^{-1}$ para o capim-Colonião e $2,9 \mathrm{~g} \mathrm{~kg}^{-1}$ para o capimBraquiária.

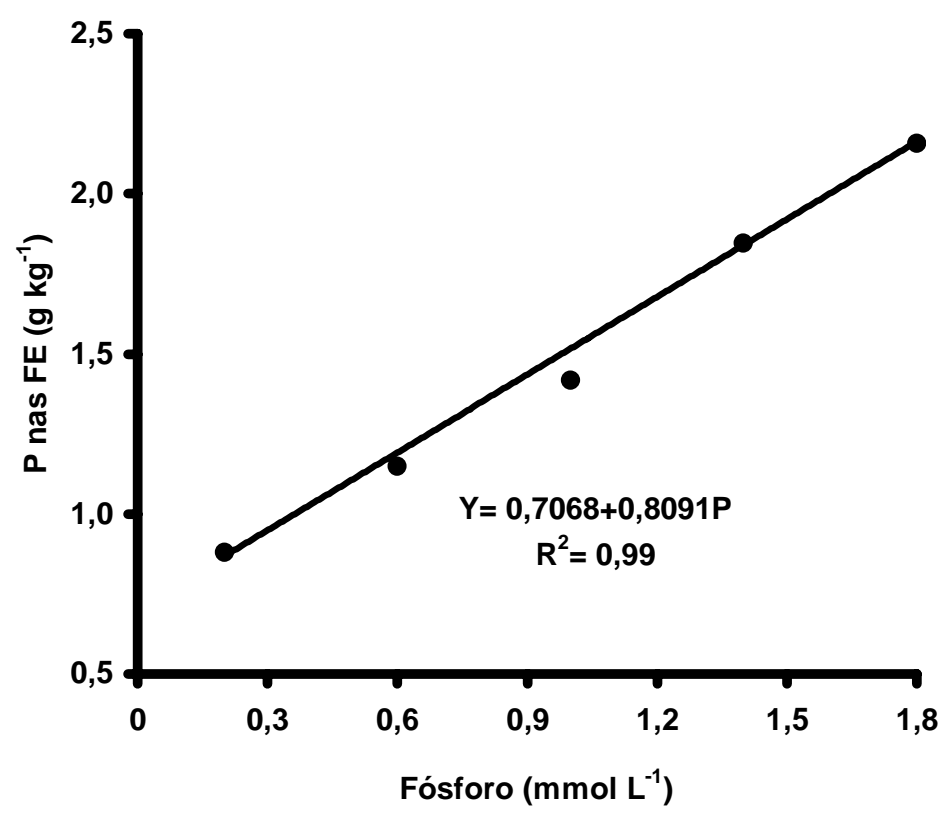

Figura 20 - Concentração de fósforo nas folhas emergentes (FE) do capimTanzânia, no segundo corte, em função das doses de fósforo 


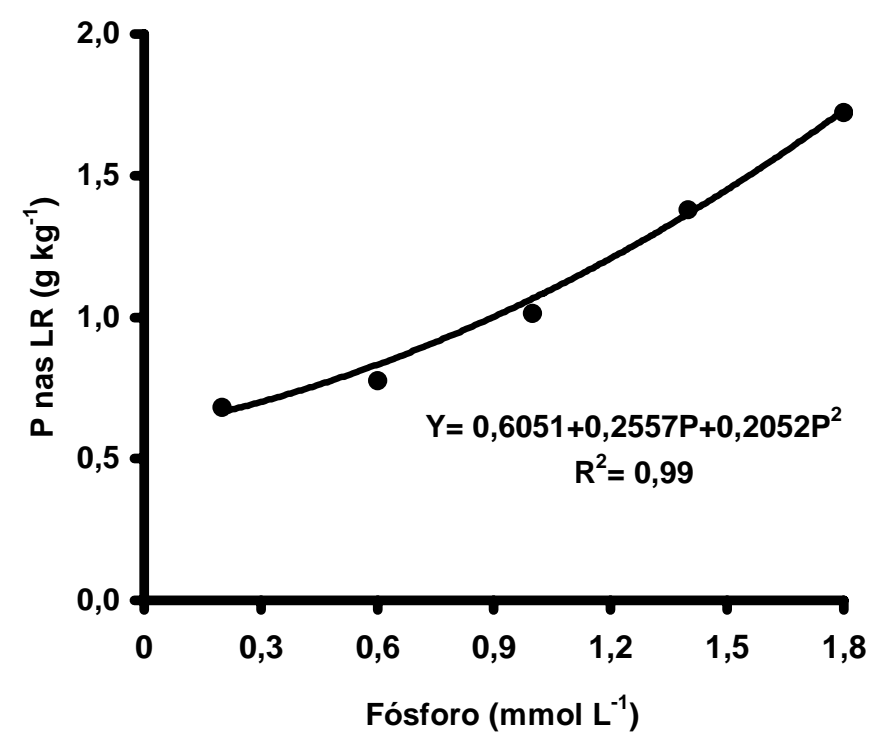

Figura 21 - Concentração de fósforo nas lâminas recém-expandidas (LR) do capim-Tanzânia, no segundo corte, em função das doses de fósforo

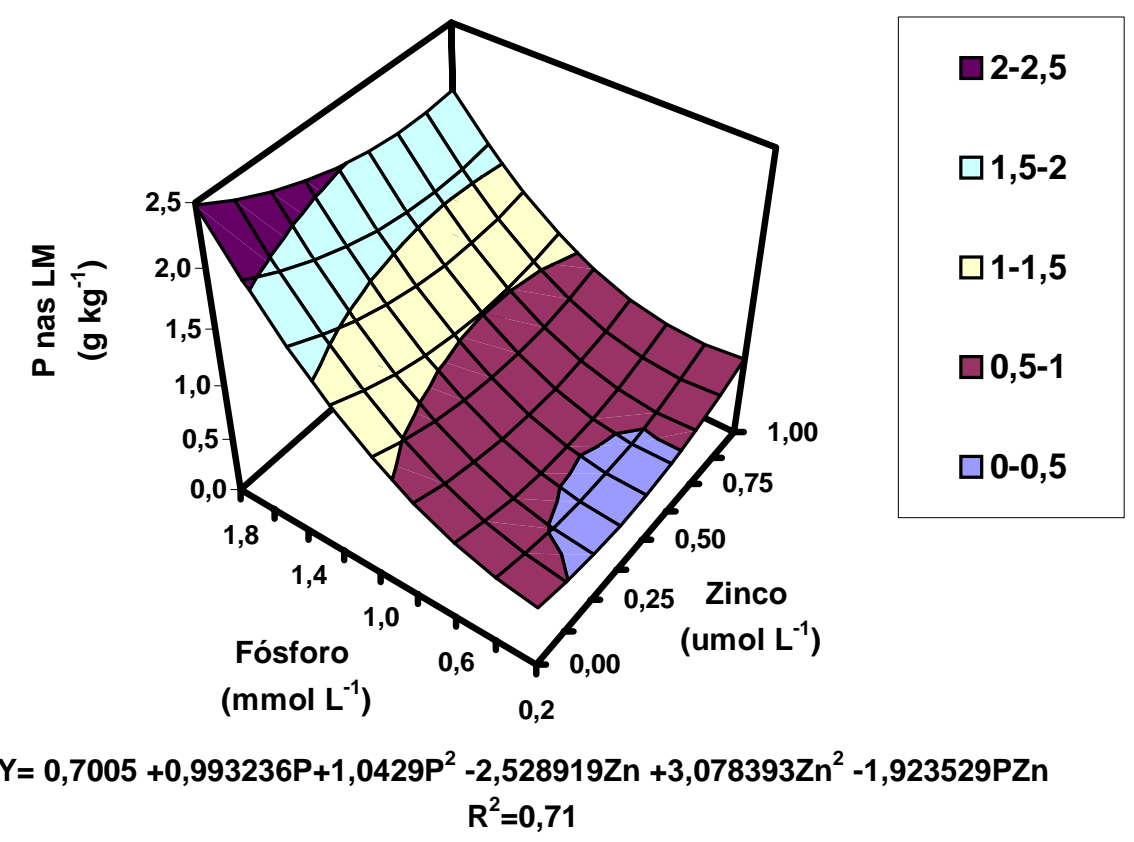

Figura 22 - Concentração de fósforo nas lâminas de folhas maduras (LM) do capim-Tanzânia, na ocasião do segundo corte, em função das doses de fósforo e de zinco 


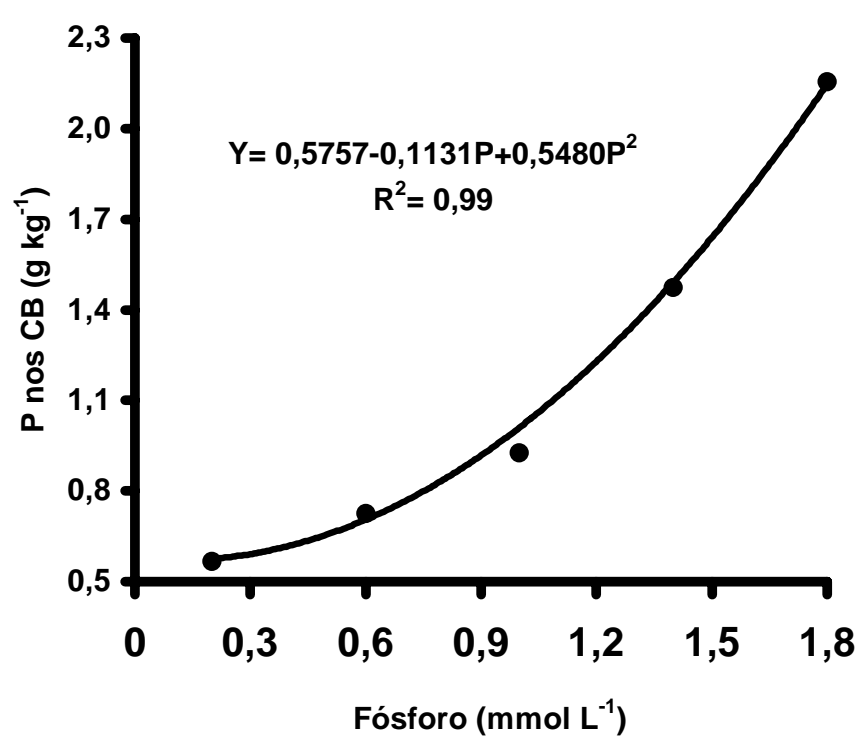

Figura 23 - Concentração de fósforo nos colmos mais bainha (CB) do capimTanzânia, na ocasião do segundo corte, em função das doses de fósforo

A concentração média de fósforo no capim-Tanzânia apresentou um comportamento no material do primeiro e outro no do segundo corte. No primeiro corte, a interação entre as doses de fósforo e de zinco foi significativa (Figura 24). No segundo corte a interação entre as dose de fósforo e zinco não foi significativa, obtendo-se significância apenas para as doses de fósforo (Figura 25). A concentração média de fósforo na parte aérea no segundo crescimento variou de 0,60 a $2,06 \mathrm{~g} \mathrm{~kg}^{-1}$ de fósforo.

Gheri et al. (2000) encontraram concentrações médias de fósforo nas plantas que variaram para solos de textura arenosa de 0,95 a 1,21 g kg-1 no primeiro corte e de 0,84 a $1,00 \mathrm{~g} \mathrm{~kg}^{-1}$ no segundo corte da menor para a maior dose de fósforo aplicada, respectivamente. Para os solos de textura média esses valores variaram de 1,18 a $0,95 \mathrm{~g} \mathrm{~kg}^{-1}$ no primeiro corte e 0,98 a 0,79 no segundo corte. No solo argiloso a concentração de fósforo nas plantas foi de 1,17 a 1,39 $\mathrm{g} \mathrm{kg}^{-1}$ no primeiro corte e 0,84 a $1,17 \mathrm{~g} \mathrm{~kg}^{-1}$ no segundo corte. 


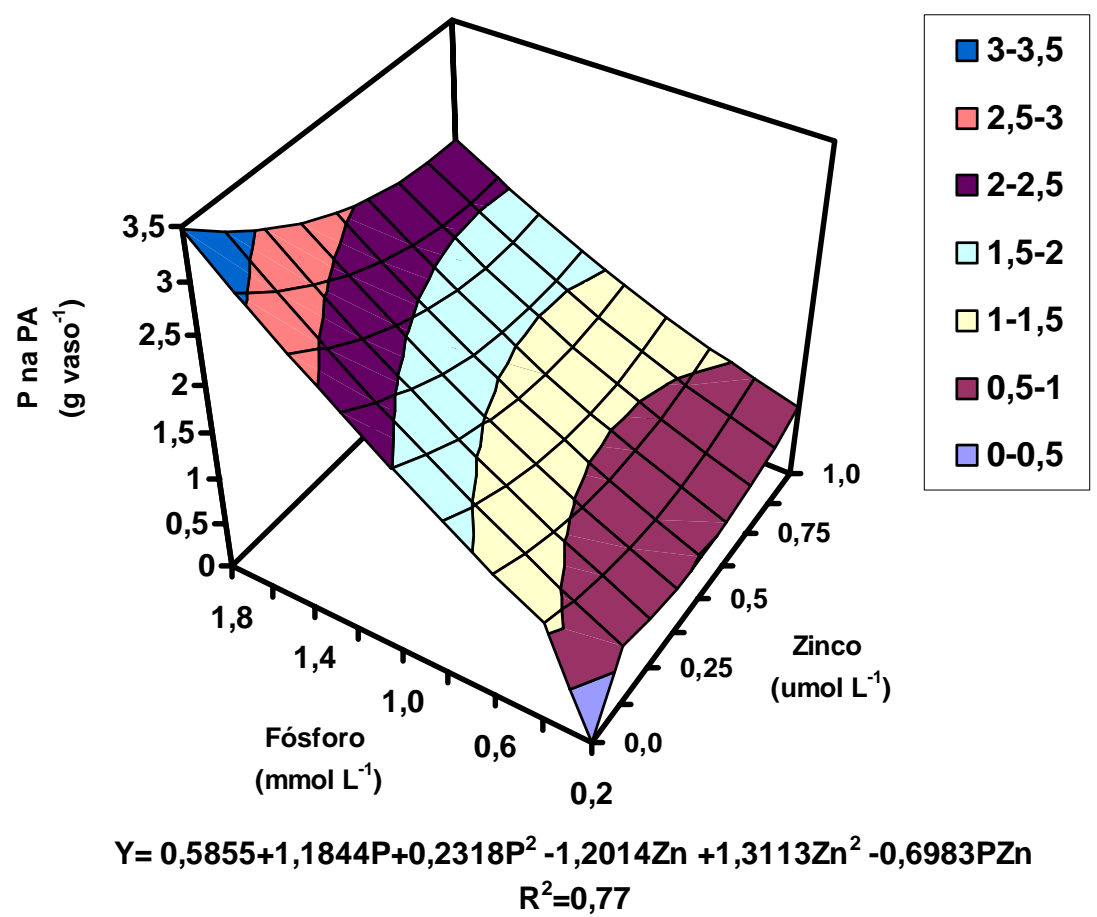

Figura 24- Concentração média de fósforo na parte aérea do capim-Tanzânia, na ocasião do primeiro corte, em função das combinações de doses de fósforo e de zinco

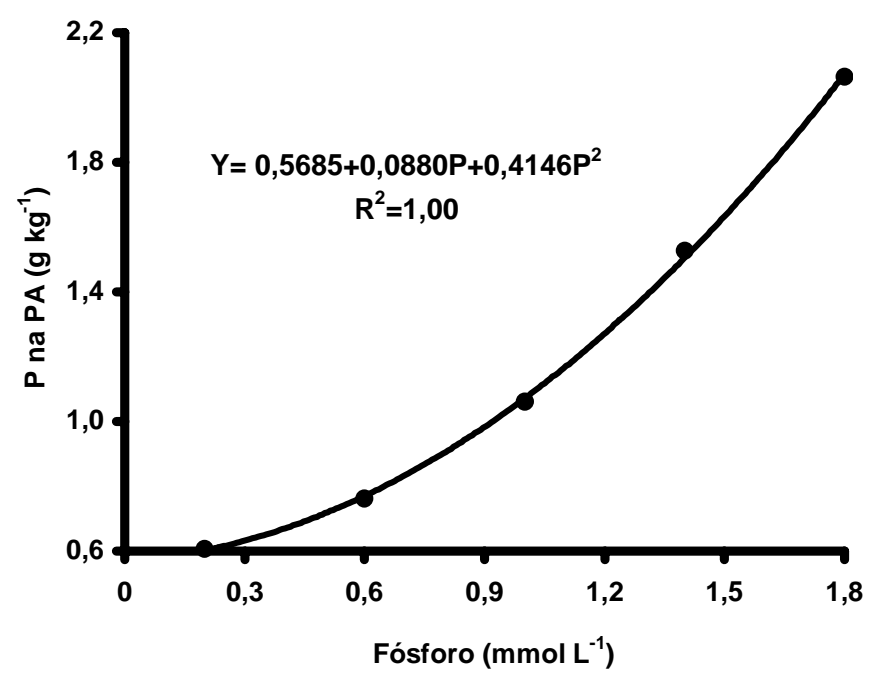

Figura 25 - Concentração média de fósforo na parte aérea (PA) do capimTanzânia na ocasião do segundo corte, em função das doses fósforo 
Nóbrega (1999) observou que a concentração média de fósforo no capim-Elefante foi de $1,2 \mathrm{~g} \mathrm{~kg}^{-1}$, quando o espaçamento utilizado foi de $0,5 \mathrm{~m}$ entre plantas e a adubação localizada. Quando a aplicação do adubo foi distribuída, encontrou concentração de fósforo na planta com o valor de 1,4 $\mathrm{g} \mathrm{kg}^{-1}$. Hoffmann et al. (1995), trabalhando com doses de fósforo de 0, 75, 150, 225 e $450 \mathrm{mg} \mathrm{kg}^{-1}$ para o capim-Colonião, verificaram que a concentração média de fósforo foi de $2,6 \mathrm{~g} \mathrm{~kg}^{-1}$ para o primeiro corte e de $2,4 \mathrm{~g} \mathrm{~kg}^{-1}$ para o segundo corte.

\subsubsection{Fósforo nas raízes}

A interação entre as doses de fósforo e de zinco não apresentou significância quanto à concentração de fósforo nas raízes do capim-Tanzânia. A significância foi constatada para esta variável em termos das doses de fósforo supridas na solução, ajustando-se os resultados ao modelo de segundo grau (Figura 26). A máxima concentração de fósforo seria encontrada na dose 2,1 $\mathrm{mmol} \mathrm{L}^{-1}$ de fósforo, portanto, acima dos valores estudados neste trabalho.

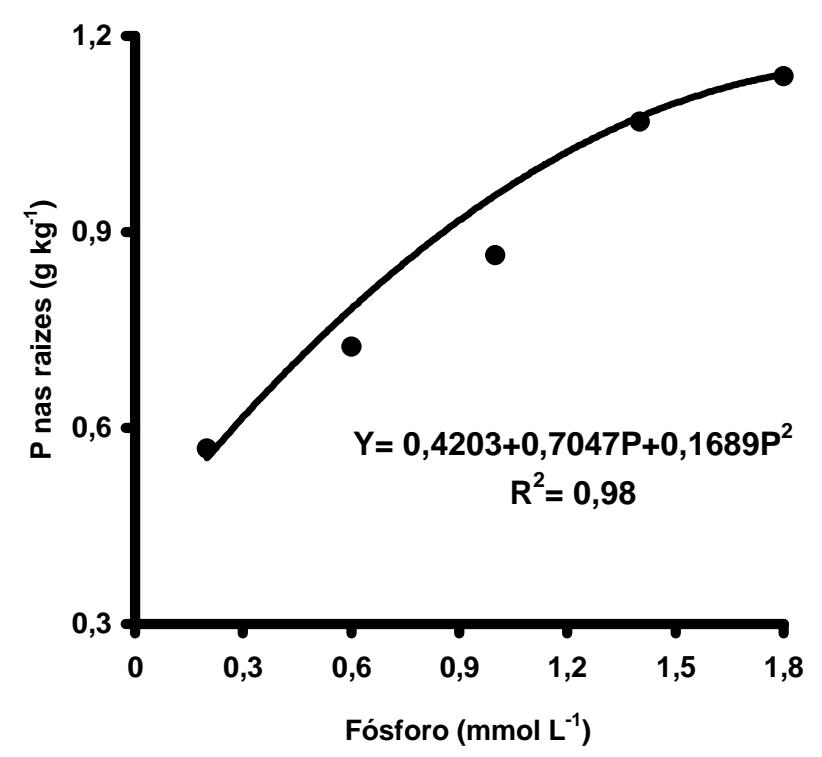

Figura 26 - Concentração de fósforo nas raízes do capim-Tanzânia, em função das doses de fósforo 
Almeida (1998) aplicou fósforo na solução nutritiva até a dose de 31 $\mathrm{mg} \mathrm{L}^{-1}$ e constatou aumento linear da concentração de fósforo nas raízes da Brachiaria decumbens e da Brachiaria brizantha.

Rossi (1999) observou aumento linear da concentração de fósforo nas raízes do capim-Braquiária e do capim-Colonião quando aplicou fósforo na solução nutritiva nas doses de 3,1, 15,5 e $31 \mathrm{mg} \mathrm{L}^{-1}$.

Melo (2005) não encontrou respostas para a concentração de fósforo nas raízes do capim-Marandu, quando aplicou doses desse nutriente de 0 a 330 $\mathrm{mg} \mathrm{dm}^{-3}$ num Latossolo Vermelho-Amarelo.

Silva (1996), em experimento com doses de fósforo de 3,1, 15,5 e 31 $\mathrm{mg} \mathrm{L}^{-1}$ em solução nutritiva, observou que a concentração de fósforo nas raízes ajustou-se ao modelo linear de regressão.

\subsubsection{Zinco na parte aérea}

A interação entre as doses de fósforo e de zinco foi significativa para a concentração de zinco nas lâminas de folhas emergentes (FE) ajustando-se os resultados ao modelo polinomial de regressão (Figura 27). Para as demais partes da planta, ocorreram significâncias para as doses de fósforo e de zinco, separadamente. As concentrações de zinco nas lâminas de folhas recémexpandidas (LR) e nos colmos+bainhas (CB) variaram em função das doses de fósforo ajustando-se ao modelo quadrático de regressão (Figuras 28 e 31). Para as lâminas de folhas maduras (LM), a concentração de zinco variou em função das doses de fósforo e das doses de zinco, com ajustes de resultados ao modelo quadrático de regressão para fósforo e linear para o zinco (Figuras 29 e 30). A mínima concentração de zinco em função das doses de fósforo foi encontrada nas lâminas de folhas recém-expandidas na dose de $1,30 \mathrm{mmol} \mathrm{L}^{-1}$, nas lâminas de folhas maduras na dose de $1,38 \mathrm{mmol} \mathrm{L}^{-1}$ e nos colmos mais bainhas na dose de $1,25 \mathrm{mmol} \mathrm{L}^{-1}$. 
A variação na concentração de zinco em função das doses de fósforo (Figuras 28, 29 e 31) pode ser explicada pelo fato das plantas apresentarem menor crescimento nas doses mais baixas de fósforo, acumulando zinco nas folhas.

Outra hipótese é o fato de que com o aumento das doses de fósforo, ocorre diminuição da concentração de zinco nas plantas. Esta interação entre nutrientes foi estudada no presente trabalho e é clássica na literatura, citada por Marschner (1995), Malavolta et al. (1997) e Mengel \& Kirkby (2001). Estes autores descrevem que o zinco diminui em função das doses de fósforo pela precipitação como fosfato de zinco.

Souza et al. (1998) verificaram diferenças significativas na concentração de zinco nas folhas de milho em função das doses de zinco aplicadas ao solo para o milho. A variação na concentração de zinco não foi constatada, neste mesmo trabalho, em função das doses de fósforo adicionadas ao solo.

Galrão (1995) observou variação na concentração de zinco na planta de milho de 16 a $28 \mathrm{mg} \mathrm{kg}^{-1}$ da não aplicação desse micronutriente para a dose de zinco de $9 \mathrm{~kg} \mathrm{ha}^{-1}$, respectivamente.

No presente trabalho, o zinco nas lâminas de folhas recémexpandidas (LR) variou de 7,92 a $10,70 \mathrm{mg} \mathrm{kg}^{-1}$ (Figura 28), estando estes valores abaixo do nível crítico recomendado para as culturas em geral, que está aproximadamente entre 15 e $20 \mathrm{mg} \mathrm{kg}^{-1}$ (Marschner, 1995). 

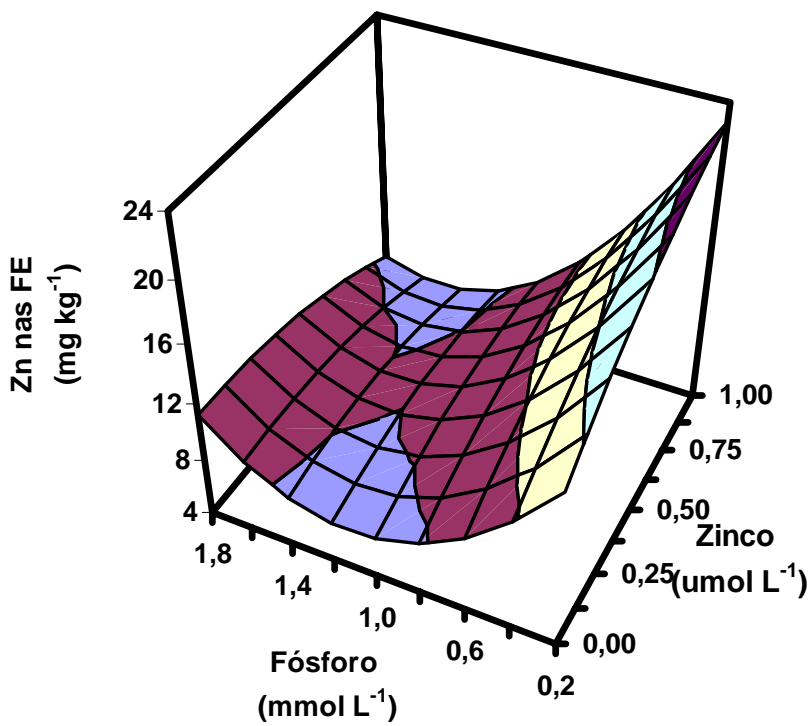

$Y=18,7186-21,5872+9,6806 P^{2}+13,7218 Z n-4,2175 Z^{2}-7,4007 P Z n$

$$
R^{2}=0,62
$$

Figura 27 - Concentração de zinco nas folhas emergentes (FE) do capimTanzânia, na ocasião do primeiro corte, em função das combinações entre doses de fósforo e de zinco

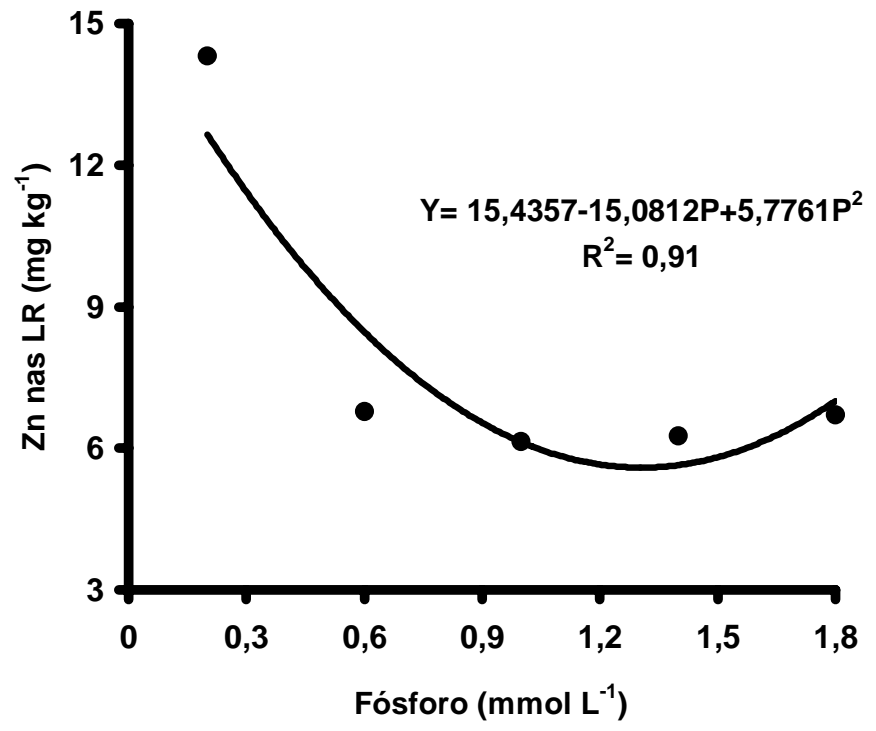

Figura 28- Concentração de zinco nas lâminas de folhas recém expandidas (LR) do capim-Tanzânia, no primeiro corte, em função das doses de fósforo 


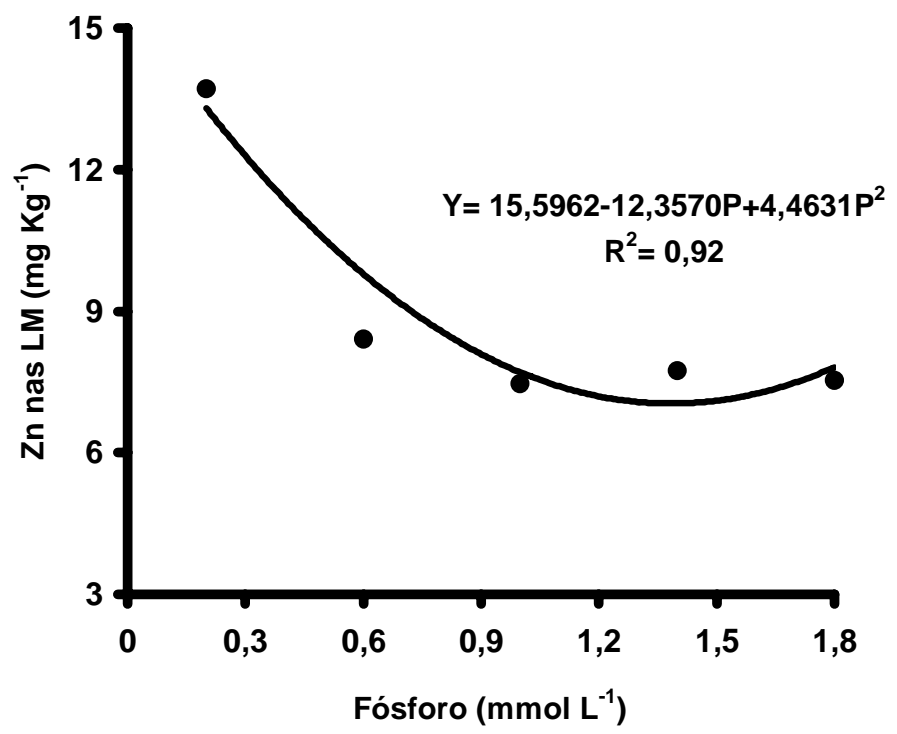

Figura 29- Concentração de zinco nas lâminas de folhas maduras (LM) do capim-Tanzânia, na ocasião do primeiro corte, em função das doses de fósforo

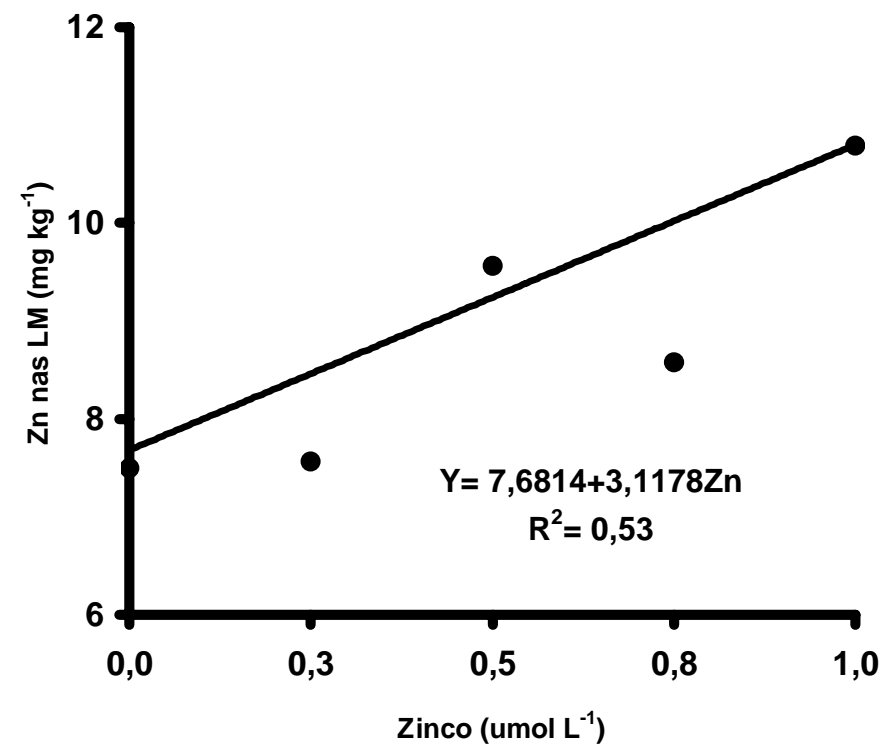

Figura 30 - Concentração de zinco nas lâminas de folhas maduras (LM) do capim-Tanzânia, na ocasião do primeiro corte, em função das doses de zinco 


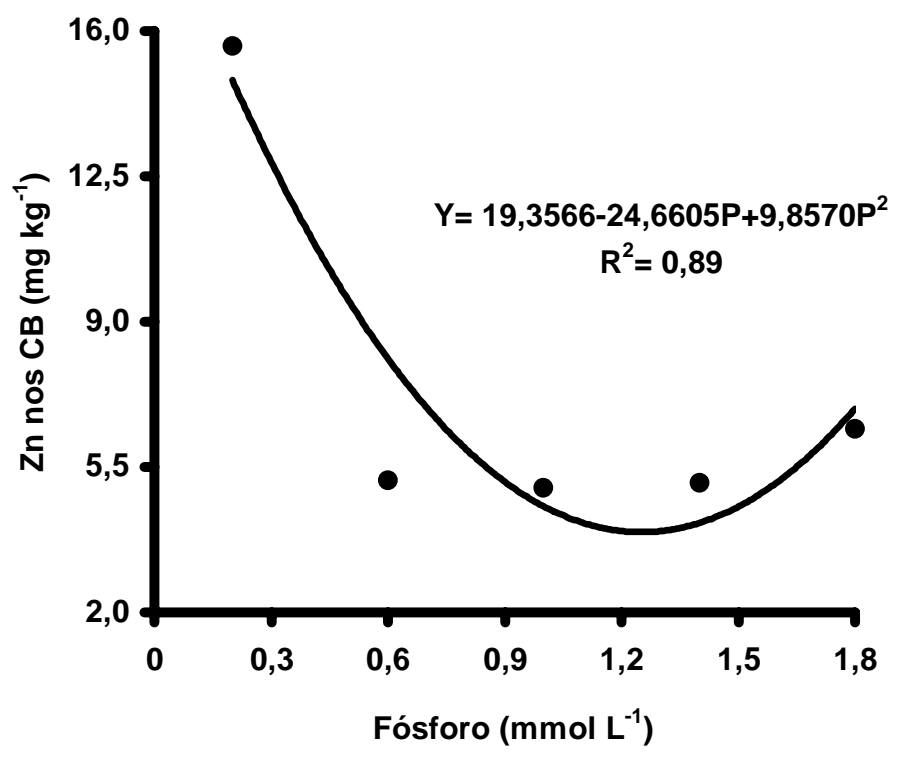

Figura 31 - Concentração de zinco nos colmos mais bainhas (CB) do capimTanzânia, na ocasião do primeiro corte, em função das doses de fósforo

Quanto ao segundo corte, a interação entre as doses de fósforo e de zinco não foi significativa para a concentração de zinco nas partes das plantas, sendo que se verificaram significâncias para as folhas emergentes, lâminas de folhas recém-expandidas, lâminas de folhas maduras e colmos mais bainhas, em função das doses de fósforo supridas no substrato (Figuras 32, 33, 34 e 35). Não foram encontradas significâncias para as concentrações de zinco em qualquer das partes das plantas de capim-Tanzânia, em função das doses de zinco.

Os mínimos valores de concentração de zinco foram encontrados nas folhas emergentes na dose de fósforo de 1,57, nas lâminas de folha recémexpandidas na dose de 1,59, nas lâmina de folhas maduras na dose de 1,58 e nos colmos mais bainhas na dose de $1,34 \mathrm{mmol} \mathrm{L}^{-1}$. 


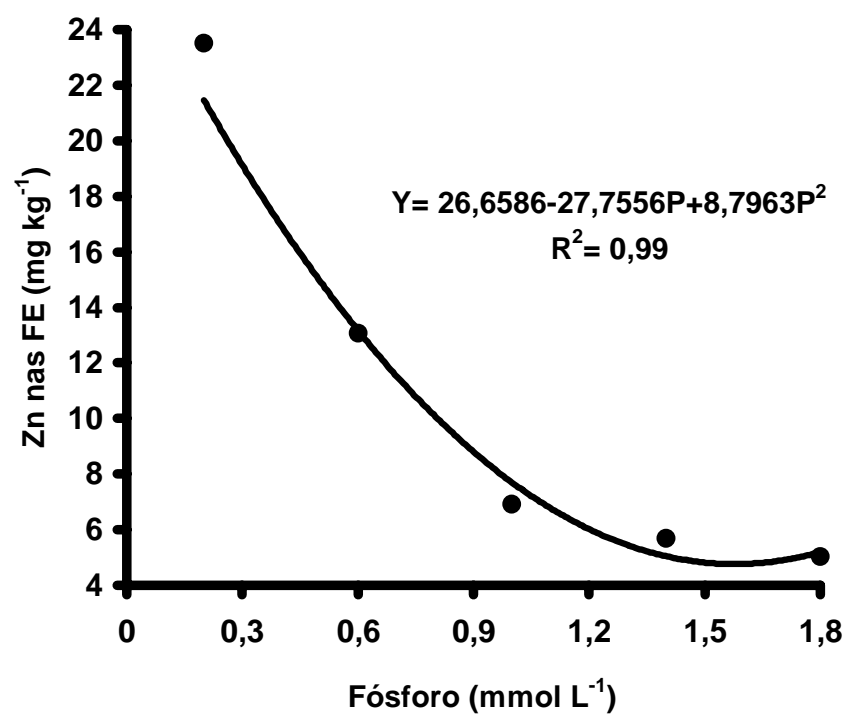

Figura 32 - Concentração de zinco nas folhas emergentes (FE) do capimTanzânia, na ocasião do segundo corte, em função das doses de fósforo

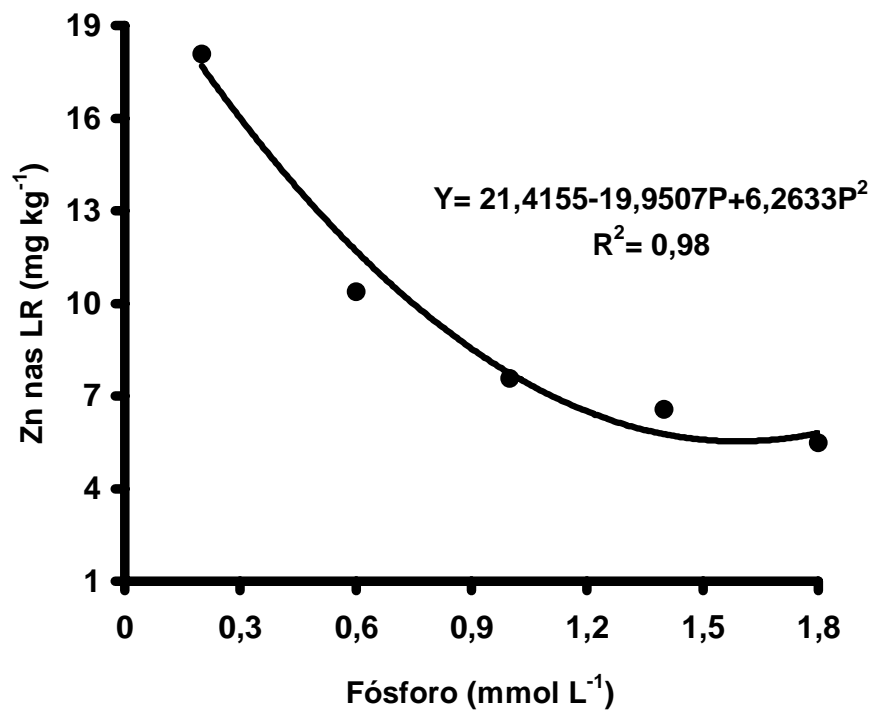

Figura 33 - Concentração de zinco nas lâminas recém-expandidas (LR) do capim-Tanzânia, no segundo corte, em função das doses de fósforo 


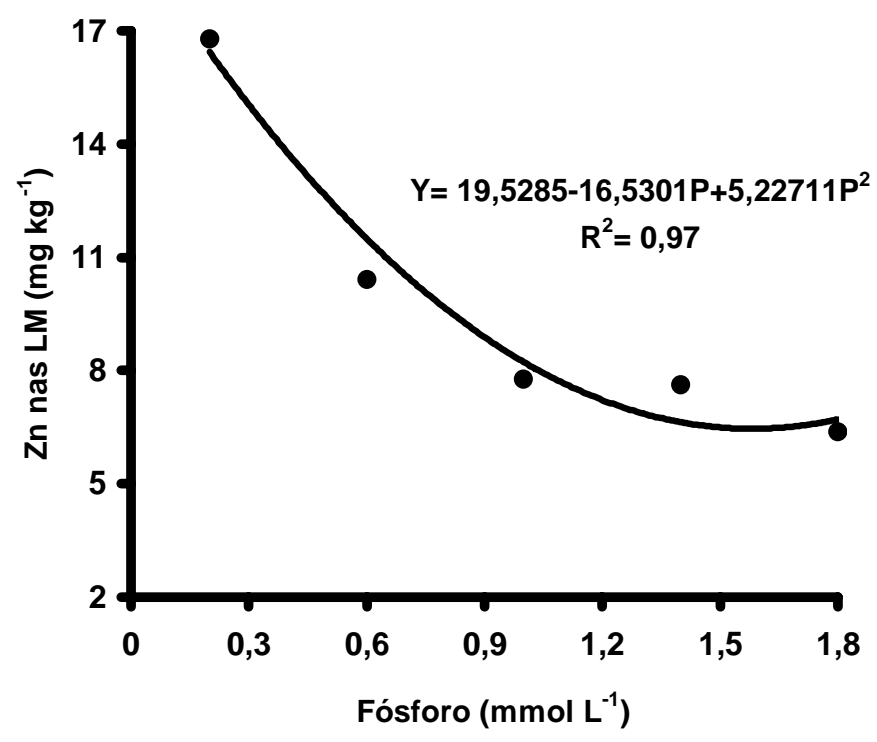

Figura 34 - Concentração de zinco nas lâminas de folhas maduras (LM) do capim-Tanzânia, no segundo corte, em função das doses de fósforo

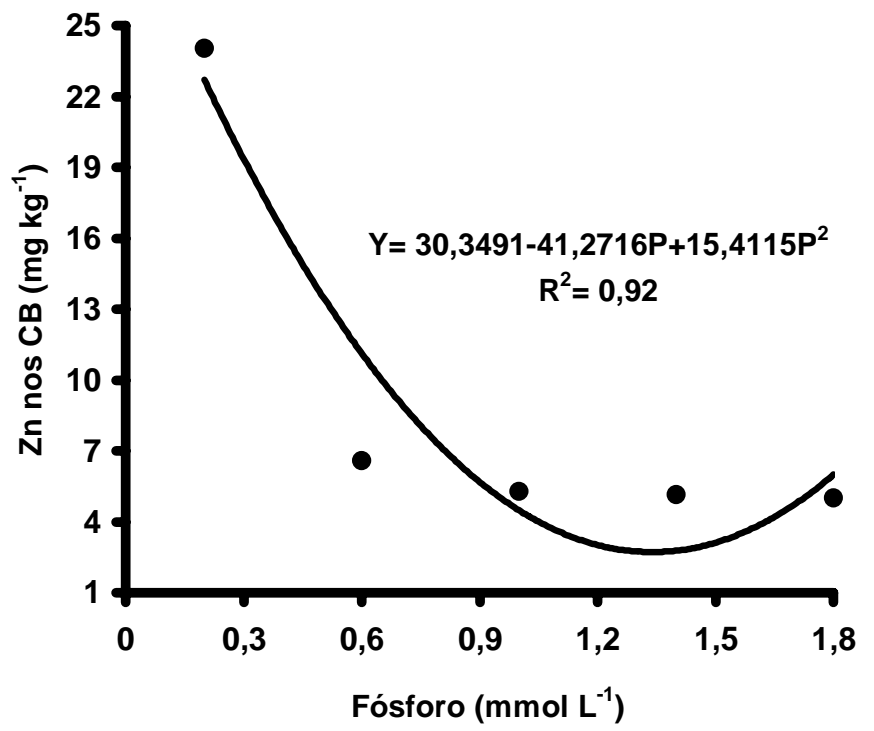

Figura 35 - Concentração de zinco nos colmos mais bainhas (CB) do capimTanzânia, na ocasião do segundo corte, em função das doses de fósforo 
A interação entre as doses de fósforo e de zinco não foi significativa para a concentração média de zinco na parte aérea da forrageira coletada tanto no primeiro como segundo cortes das plantas. Houve significância para a concentração média de zinco na parte aérea das plantas, no primeiro e no segundo corte, apenas em função das doses de fósforo. A mínima concentração média de zinco na parte aérea do capim foi encontrada na dose de fósforo de $1,31 \mathrm{mmol} \mathrm{L}^{-1}$ no primeiro corte e de $1,41 \mathrm{mmol} \mathrm{L}^{-1}$ no segundo corte.

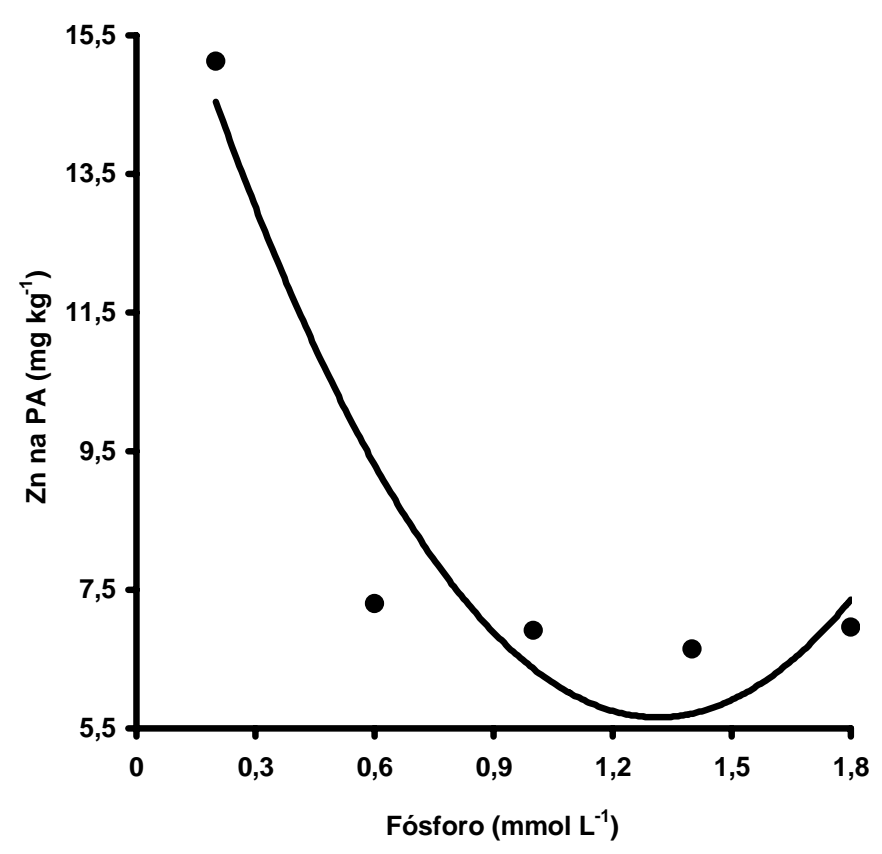

Figura 36 - Concentração média de zinco na parte aérea do capim-Tanzânia, na ocasião do primeiro corte, em função das doses de fósforo

A concentração média de zinco nas plantas diminuiu com o aumento das doses de fósforo, ocorrendo interação entre as doses desses dois nutrientes para o capim-Tanzânia. Esta diminuição na concentração pode estar relacionada com a precipitação do zinco, na forma de fosfato de zinco que impede que a planta absorva o micronutriente. 


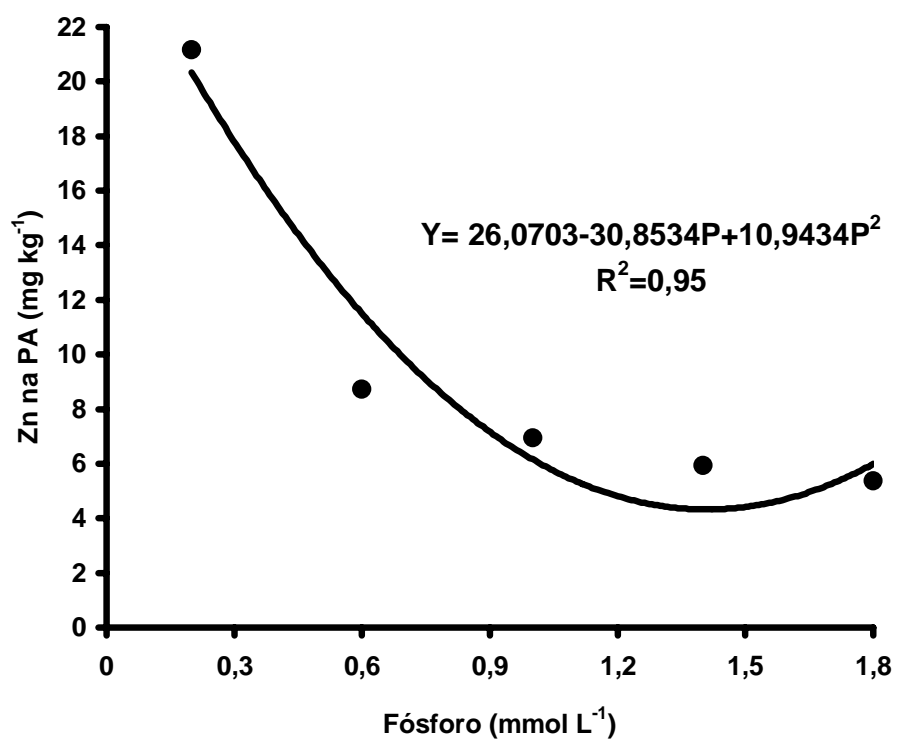

Figura 37 - Concentração média de zinco na parte aérea do capim-Tanzânia, na ocasião do segundo corte, em função das doses de fósforo

\subsubsection{Zinco nas raízes}

A interação entre as doses de fósforo e zinco não foi significativa para a concentração de zinco nas raízes das plantas. Ocorreu significância apenas em função das doses de zinco adicionadas ao substrato, ajustando-se ao modelo linear de regressão (Figura 38).

Loneragan et al. (1982) aplicaram doses de sulfato de zinco de 0,0; 0,25; 1,00 e 2,00 $\mu \mathrm{mol}$ em solução nutritiva em plantas de quiabo e concluíram que a concentração de zinco nas raízes aumentou significativamente da não aplicação para as demais doses. 


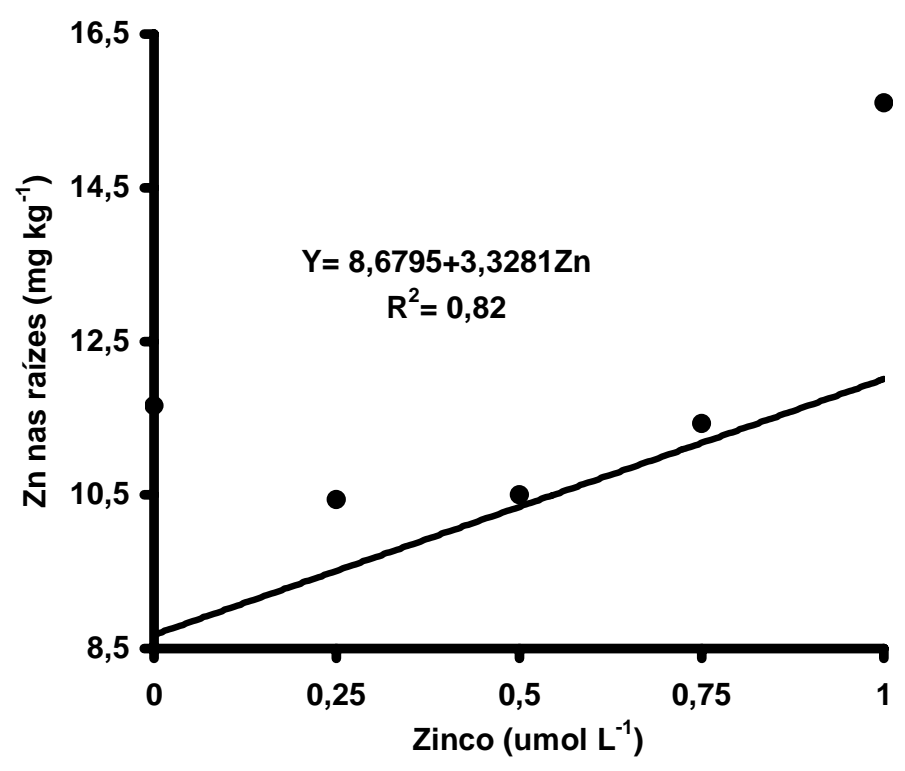

Figura 38- Concentração de zinco nas raízes do capim-Tanzânia, em função das doses de fósforo

\subsection{Sintomas visuais}

Observaram-se sintomas visuais da deficiência de fósforo e de zinco nas plantas tanto no primeiro como no segundo crescimentos do capimTanzânia. A carência de fósforo se traduziu por diminuição no porte das plantas, no perfilhamento, no número de folhas, o que comprometeu o crescimento do capim (Figura 39), desde as fases iniciais de desenvolvimento no primeiro e segundo períodos de cultivo das plantas.

Quanto ao zinco, verificou-se que nas doses mais baixas do fornecimento desse micronutriente as folhas apresentaram manchas esbranquiçadas na região da nervura central e traços marrons próximos às pontas das lâminas foliares (Figura 40). 


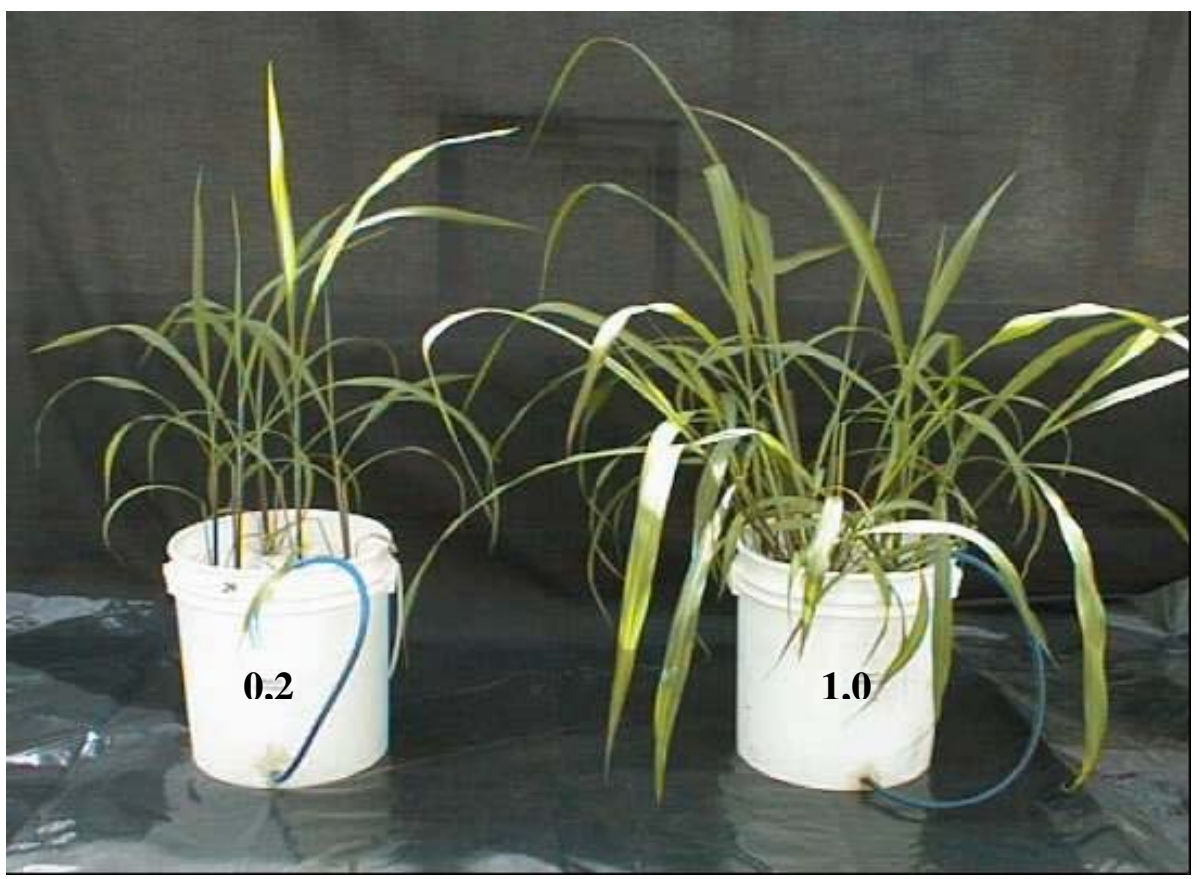

Figura 39 - Diferenças notadas visualmente no perfilhamento, no número de folhas e na quantidade de massa verde do capim-Tanzânia entre duas doses de fósforo na solução nutritiva

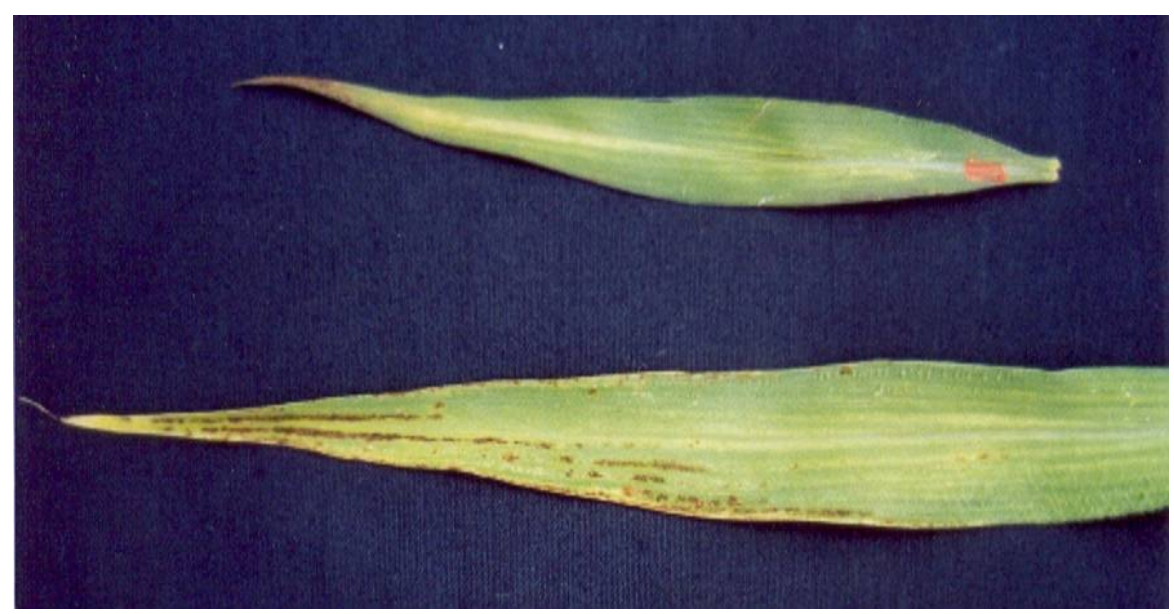

Figura 40 - Manchas esbranquiçadas próximas à nervura central e traços marrons próximos às pontas das lâminas foliares das plantas crescidas em condições das mais baixas doses de zinco 


\section{CONCLUSÕES}

$\sqrt{ }$ A produção da parte aérea no primeiro corte, a massa seca de raízes, área foliar no segundo corte, a concentração de fósforo nas lâminas de folhas maduras nos dois crescimentos e a concentração de fósforo da parte aérea do capim-Tanzânia dependem das combinações de doses de fósforo e de zinco;

$\sqrt{ }$ As doses de fósforo são determinante para o número de perfilhos e de folhas nos dois crescimentos, a produção da parte aérea no segundo corte, o comprimento e a superfície de raízes, a área foliar no primeiro corte, a concentração de fósforo em várias partes amostradas em ambos os cortes do capim-Tanzânia;

$\sqrt{ } \mathrm{O}$ fornecimento de fósforo na solução nutritiva para o capimTanzânia altera a concentração desse nutriente nas lâminas de folhas maduras no primeiro crescimento do capim-Tanzânia;

$\sqrt{ }$ A aplicação de doses de zinco incrementa a concentração desse nutriente nas lâminas de folhas maduras no primeiro crescimento do capimTanzânia e

$\sqrt{ }$ Para o capim-Tanzânia, a carência de fósforo se manifesta no porte menor das plantas, enquanto na deficiência de zinco as folhas exibem 
manchas esbranquiçadas na região da nervura central e traços marrons próximos às pontas das lâminas foliares. 


\section{REFERÊNCIAS BIBLIOGRÁFICAS}

ALMEIDA, J.C.R. de. Combinação de doses de fósforo e magnésio na produção e nutrição de duas Braquiárias. Piracicaba, 1998. 81p. Dissertação (Mestrado) - Escola Superior de Agricultura "Luiz de Queiroz", Universidade de São Paulo.

ANDRÈ, E.M.; CRUZ, M.C.P.; FERREIRA, M.E. et al. Frações de zinco em solo arenoso e suas relações com disponibilidade para Cynodon spp. cv. Tifton85. Revista Brasileira de Ciência do Solo, v.27, p.451-459, 2003.

BAR-AKIVA, A.; LAVON, R. Carbonic anhydrase activity as an indicator of zinc deficiency in citrus leaves. Journal of Horticultural Science, v.44, p.359362, 1969.

BATISTA, K. Respostas do capim-Marandu a combinações de doses de nitrogênio e enxofre. Piracicaba, 2002. 91p. Dissertação (Mestrado) Escola Superior de Agricultura "Luiz de Queiroz", Universidade de São Paulo.

BRITO FILHO, M.R.T.; CECATO, U.; GUERRA, F.H. et al. Efeito da adubação nitrogenada e fosfatada sobre o perfilhamento do capim-Marandu (Brachiaria brizantha Stapf cv. Marandu). In: REUNIÃO ANUAL DA SOCIEDADE BRASILEIRA DE ZOOTECNIA, 36., Porto Alegre, 1999. Anais. Porto alegre: SBZ, 1999. p. 90. 
BOWN, L.C.; LEGGETT, G.E. Phosphorus and zinc concentrations in russet burbank potato tissues in reaction to development of zinc deficiency symptoms. Soil Science Society of America Proceedings, v.28, p.229232, 1964.

BUZETTI, S.; MURAOKA, T.; MAURO, A.O. Doses de zinco em diferentes condições de acidez de um solo de Cerrado. Pesquisa Agropecuária Brasileira, v.26, p.913-918, 1991.

CAKMAK, I.; MARSCHNER, H.; BANGERTH. F.; FRITZ, B. Effect of zinc nutritional status on growth, protein, metabolism and levels of indole-3-acetic acid and other phytohormones in bean (Phaseolus vulgaris L.). Journal Experimental Botany, v.40, p.405-412, 1989.

CORRÊA, F.L.O.; SOUZA, C.A.S.; CARVALHO, J.G. et. al. Fósforo e zinco no desenvolvimento de mudas de aceroleira. Revista Brasileira de Fruticultura, v.24, p.793-796, 2002.

CORRÊA, L.A. Níveis críticos de fósforo para o estabelecimento de Brachiaria decumbens Stapf., Brachiaria brizantha (Hochst.) Stapf. cv. Marandu e Panicum maximum Jacq., em Latossolo Vermelho-Amarelo, álico. Piracicaba, 1991. 83p. Tese (Doutorado) - Escola Superior de Agricultura "Luiz de Queiroz". Universidade de São Paulo.

CORRÊA, L.A.; FREITAS, A.R. de. Adubação fosfatada na produção e no teor de fósforo em quatro cultivares de Panicum maximum. In: REUNIÃO ANUAL DA SOCIEDADE BRASILEIRA DE ZOOTECNIA, 34., Juiz de Fora, 1997. Anais. Juiz de Fora: SBZ, 1997. p.157-159. 
CORRÊA, L.A.; FREITAS, A.R. de; EUCLIDES, V.P.B. Níveis críticos de fósforo para o estabelecimento de quatro cultivares de Panicum maximum em Latossolo Vermelho-Amarelo, álico. In: REUNIÃO ANUAL DA SOCIEDADE BRASILEIRA DE ZOOTECNIA, 33., Fortaleza, 1996. Anais. Fortaleza: SBZ, 1996. p.169-170.

CORSI, M. Manejo de plantas forrageiras do gênero Panicum. In: SIMPÓSIO SOBRE MANEJO DE PASTEGEM, 9., Piracicaba, 1988. Anais. Piracicaba: FEALQ, 1988. p.57-75.

FAGERIA, N.K. Níveis adequados e tóxicos de zinco na produção de arroz, feijão, milho, soja e trigo em solo de Cerrado. Revista Brasileira de Engenharia Agrícola e Ambiental, v.4, p.390-395, 2000.

FAGERIA, N.K.; STONE, L.F. Produtividade de feijão no sistema de plantio direto com aplicação de calcário e zinco. Pesquisa Agropecuária Brasileira, v.39, p.73-78, 2004.

FANCELLI, A.L. Efeitos da interação fósforo-zinco na produção e na qualidade de sementes de sorgo granífero (Sorghum bicolor (I.) Moench). Piracicaba, 97p. Dissertação (Mestrado) - Escola Superior de Agricultura "Luiz de Queiroz", Universidade de São Paulo.

GALRÃO, E.Z. Níveis críticos de zinco para o milho cultivado em Latossolo Vermelho-Amarelo, fase cerrado. Revista Brasileira de Ciência do Solo, v.19, p.255-260, 1995.

GALRÃO, E.Z.; MESQUITA FILHO, M.V. de. Efeito de fontes de zinco na produção de matéria seca do milho em solo sob Cerrado. Revista Brasileira de Ciência do Solo, v.5, p.167-170, 1981a 
GALRÃO, E.Z.; MESQUITA FILHO, M.V. de. Efeito de micronutrientes na produção e composição química do arroz (Oryza sativa L.) e do milho (Zea mays L.) em solo de Cerrado. Revista Brasileira de Ciência do Solo, v.5, p.72-75, $1981 b$.

GARCEZ NETO,A.; NASCIMENTO JUNIOR, D.do.; REGAZZI, A.J.; et.al. Respostas morfogênicas e estruturais de Panicum maximum cv. Mombaça sob diferentes níveis de adubação nitrogenada e alturas de corte. Revista Brasileira de Zootecnia, v.31, p. 1890-1900, 2002.

GHERI, E.O.; CRUZ, M.C.P.; FERREIRA, M.E. et al. Nível crítico de fósforo para Panicum maximum Jacq. cv. Tanzânia. Pesquisa Agropecuária Brasileira, v.35, p.1809-1816, 2000.

HERNÁNDES, M.; CÁRDENAS, M. Fertilizacion PZn em Panicum maximum cv. Likoni. Pastos y Forrajes, v.13, p.53-58, 1990.

HOFFMANN, C.R.; FAQUIN, V.; GUEDES, G.A.A. et al. O nitrogênio e o fósforo no crescimento da braquiária e do colonião em amostras de um Latossolo da região Noroeste do Paraná. Revista Brasileira de Ciência do Solo, v.19, p.79-86, 1995.

JANK, L. Potencial do gênero Panicum. In: SIMPÓSIO DE FORRAGENS E PASTAGENS, Campinas, 1994. Anais. Campinas: CBNA, 1994. p.25-31.

JANK, L. O capim-Colonião. In: SIMPÓSIO SOBRE MANEJO DE PASTAGEM, 12., Piracicaba, 1995. Anais. Piracicaba: FEALQ, 1995, p.21-58. 
JANK, L.; SAVIDAN, Y.; SOUZA, M.T. et al. Avaliação do germoplasma de Panicum maximum introduzido da África. 1. Produção forrageira. Revista da Sociedade Brasileira de Zootecnia, v. 23, p. 433-440, 1994.

KANNO, T.; MACEDO, M.C.M.; UOZUMI, S. et al. Development of grassland management technology for sustainable agropastoral systems in the subtropical zone in Brazil. JIRCAS Working Report, v.19, p.63-73, 2001.

LITTELL, R.C.; MOTT, G.O. Computer assisted design and analysis of response surface experiments in agronomy. Soil and Crop Society of Florida Proceedings, v.34, p.94-97, 1975.

LONERAGAN, J.F.; GRUNES, D.L.; WELCH, R.M. et al. Phosphorus accumulation and toxicity in leaves in relation to zinc supply. Soil Science Society American Journal, v.46, 1982.

LOPEZ-GOROSTIAGA, E. Contribuição ao estudo das relações entre o zinco e o fósforo na nutrição das plantas. Piracicaba, 1972. 53p. Tese (Doutorado)Escola Superior de Agricultura "Luiz de Queiroz", Universidade de São Paulo.

MAGAlHÃES, A.F.; PIRES, A.J.V.; SOUSA, R.S. et al. Produção do capim Brachiaria decumbens em função de adubação nitrogenada e fosfatada no período das águas (compact disc). In: REUNIÃO ANUAL DA SOCIEDADE BRASILEIRA DE ZOOTECNIA, 41., Campo Grande, 2004. Campo Grande: SBZ, 2004. 
MAIQUE, T.; MONTEIRO, F.A. Distribuição e recuperação de fósforo e relação P:Zn na parte aérea do capim-Mombaça (compact disc). In: CONGRESSO BRASILEIRO DE CIÊNCIA DO SOLO, Ribeirão Preto, 2003. Anais. Ribeirão Preto: SBCS, 2003.

MALAVOLTA, E.; VITTI, G.C.; OLIVEIRA, S.A. Avaliação do estado nutricional das plantas: princípios e aplicações. Piracicaba: Potafos, 1997. $319 p$.

MANARIN, C.M. Respostas fisiológicas, bioquímica e produtivas do capimMombaça a doses de nitrogênio. Piracicaba, 2000. 59p. Dissertação (Mestrado) - Escola Superior de Agricultura "Luiz de Queiroz", Universidade de São Paulo.

MARSCHNER, H. Mineral nutrition of higher plants. Berlin: Academic Press, 1995. 674p.

MEIRELLES, N.M.F.; WERNER, J.C.; ABRAMIDES, P.L.G. et al. Níveis críticos de fósforo em capim-Colonião cultivado em dois tipos de solo: Latossolo Vermelho-Escuro e Podzólico Vermelho-Amarelo. Boletim de Indústria Animal, v.45, p.215-232, 1988.

MELO, E.F.; RONZELLI JUNIOR, P.; PREVEDELLO, B.M.S. et al. Avaliação dos teores de zinco no solo e em feijoeiros. Pesquisa Agropecuária Brasileira, v.27, p. 373-380, 1992.

MELO, S.P. Silício e fósforo para estabelecimento do capim-Marandu num Latossolo Vermelho-Amarelo. Piracicaba, 2005. 110p. Tese (Doutorado) Escola Superior de Agricultura "Luiz de Queiroz", Universidade de São Paulo. 
MENGEL, K.; KIRKBY, E.A. Principles of plant nutrition. Dordrecht: Kluwer Academic Publishers, 2001. 687p.

MESQUITA, E.E.; PINTO, J.C.; FURTINI NETO, A.E. et al. Teores críticos de fósforo em três solos para o estabelecimento de capim-Mombaça, capimMarandu e capim-Andropogon em vasos. Revista Brasileira de Zootecnia, v.33, p.290-301, 2004.

MONTEIRO, F.A. Nutrição mineral e adubação. In: SIMPÓSIO SOBRE MANEJO DE PASTAGEM, 12., Piracicaba, 1995. Anais. Piracicaba: FEALQ, 1995. p.219-244.

MOREIRA, M.A.; FONTES, P.C.R.; CAMARGOS, M.I. Interação zinco e fósforo em solução nutritiva influenciando o crescimento e a produtividade da alface. Pesquisa Agropecuária Brasileira. v. 36, p. 903-909, 2001.

MUNER, L.H. Disponibilidade de zinco para milho em resposta à correção da acidez e a localização de fósforo no solo. Viçosa, 1996. 102p. Dissertação (Mestrado) - Universidade Federal de Viçosa.

NÓBREGA, E.B. Efeito residual da adubação fosfatada e níveis críticos de fósforo para a produtividade do capim-Elefante (Pennisetum purpureum, Schum) cv. Napier. Viçosa, 1999. 55p. Dissertação (Mestrado) Universidade Federal de Viçosa.

OHKI, K. Effect of zinc nutrition on photosynthesis and carbonic anhydrase activity in cotton. Physiologia Plantarum, v.38, p.300-304, 1976. 
OLIVEIRA, T.N.; PAZ, L.G.; SANTOS, M.V.F. et al. Influência do fósforo e de diferentes regimes de corte na produtividade e no perfilhamento do capimde-raiz (Chloris orthonoton Doell). Revista Brasileira de Zootecnia, v. 33, p.60-67, 2004.

ORABI, A.A.; ABDEL-AZIZ, I.M.; Zinc-phosphorus relationship and effect on some biocomponents of corn (Zea mays L.) grown on a calcareous soil. Plant and Soil, v.69, p. 437-444, 1982.

PAULI, A.W.; ELLIS, R.; MOSER, H.C. Zinc uptake and translocation as influenced by phosphorus and calcium carbonate. Agronomy Journal, v.60, p. 394-396, 1968.

PORRA, R.J.; THOMPSON, W.A.; KRIEDEMANN, P.E. Determination of accurate extinction coefficients and simultaneous equations for assaying chorophylls $a$ and $b$ extracted with four different solvents: verification of the concentration of chlorophyll satandards by atomic absorption spectroscopy. Biochimica et Biophysica Acta, v. 975, p.384-394, 1989.

RAIJ, B. van. Fertilidade do solo e adubação. Piracicaba: Ceres, 1991. 343p.

ROSSI, C. Nutrição em fósforo e atividade da fosfatase ácida nos capins Braquiária e Colonião. Piracicaba, 1999. 121p. Tese (Doutorado) - Escola Superior de Agricultura "Luiz de Queiroz", Universidade de São Paulo.

ROMHELD, V. Aspectos fisiológicos dos sintomas de deficiência e toxicidade de micronutrientes e elementos tóxicos em plantas superiores. Micronutrientes e elementos tóxicos na Agricultura. Jaboticabal: POTAFOS, 2001. p.7185. 
RUPIN, R.F. Níveis críticos de fósforo no solo e na planta para o estabelecimento de capim-Elefante (Pennisetum purpureum) cv. Napier. Viçosa, 1997. 58p. Dissertação (Mestrado) - Universidade Federal de Viçosa.

SALAMI, A.U.; KENEFICK, D.G. Stimulation of growth in zinc deficient corn seedlings addition of tryptophan. Crop Science, v.10, p.291-294, 1970.

SANTOS, A.R. Diagnose nutricional e respostas do capim-Braquiária submetido a doses de nitrogênio e enxofre. Piracicaba, 1997. 115p. Tese (Doutorado) Escola Superior de Agricultura "Luiz de Queiroz", Universidade de São Paulo.

SANTOS JUNIOR, J.D.G. dos. Dinâmica do crescimento do capim-Marandu submetido a doses de nitrogênio. Piracicaba, 2001. 79p. Dissertação (Mestrado) - Escola Superior de Agricultura "Luiz de Queiroz", Universidade de São Paulo.

SARRUGE, J.R. Soluções nutritivas. Summa Phytopathologica, v.1, p.231233, 1975.

SARRUGE, J.R.; HAAG, H.P. Análises químicas em plantas. Piracicaba: ESALQ, 1974. 54p.

SAS-WINDOWS Institute Corporation. Propriety software release 6.08. Cary, 1989. 
SILVA, J.E.P. Parâmetros produtivos e atividade de fosfatase ácida em três gramíneas forrageiras cultivadas com doses de fósforo. Piracicaba, 1996. 81p. Tese (Doutorado) - Escola Superior de Agricultura "Luiz de Queiroz", Universidade de São Paulo.

SOUZA, E.C.; COUTINHO, E.L.M.; NATALE, W. et al. Respostas do milho à adubação com fósforo e zinco. Pesquisa Agropecuária Brasileira, v.33, p.1031-1036, 1998.

SOUZA, E.C.A.; SANTIAGO, G.; OLIVEIRA, L.C.L. et al. Respostas do milho (Zea mays L.) à adubação com fósforo e zinco. Científica, v.13, p.39-49, 1985.

WEBB, M.J.; LONEREGAN, J.F. Effect of zinc deficiency on growth phosphorus concentration, and phosphorus toxicity of wheat plants. Soil Science Society of America Journal, v.52, p.1676-1680, 1988.

WERNER, J.C. Adubação de pastagens. Nova Odessa: Instituto de Zootecnia, 1986. 49p. (Instituto de Zootecnia. Boletim Técnico, 18). 